\title{
実建築物におけるコンクリートの中性化進行の分析およびその予測手法の提案 ANALYSIS ON NATURAL CONCRETE CARBONATION OF ACTUAL BUILDINGS AND
SUGGESTION FOR ITS PREDICTION METHOD
}

田沼毅彦*，杉山 央**

Takehiko TANUMA and Hisashi SUGIYAMA

\begin{abstract}
In this paper, we propose a method for estimating the carbonation rate of concrete that will be used in actual buildings and subjected to natural environments. This method is established on the basis of results of an accelerated carbonation test and by taking the following three steps:

(1) Collection and analysis of past accelerated carbonation test data.

(2) Understanding of the actual progress of concrete carbonation in existing buildings subjected to natural environments.

(3) Proposal of a carbonation rate coefficient ratio (R) that correlates results of an accelerated carbonation test to results of a carbonation test in existing buildings.
\end{abstract}

Keywords : Concrete, Accelerated carbonation test, Actual buildings, Carbonation rate coefficient, Prediction method, Durability コンクリート，促進中性化試験，実建築物，中性化速度係数，予測手法，耐久性

\section{1. はじめに}

一般に，鉄筋コンクリート造建築物の物理的な耐用年数は，コン クリート中の鉄筋が耐力上問題となる形態にまで腐食した時点と考 えられる例えは中, 1)。この鉄筋腐食を招く劣化要因の代表としては, $\mathrm{CO}_{2}$ によるコンクリートの中性化があげられる。中性化深さを的確に評 価することが鉄筋コンクリート造建築物の物理的な耐用年数を定め るための一つの指標になることから例えば, 2), 中性化の進行の予測精 度を向上させることがより合理的な耐用年数評価につながる。

中性化の進行を調べるにあたっては，比較的短い期間で結果が得 られる促進中性化試験がこれまで多く行われてきており, 各種試験 条件が中性化深さに及ぼす影響などが研究されてきた 3)。試験方法 としては，1991 年の日本建築学会の指針案 ${ }^{4}$ における「コンクリー トの促進中性化試験方法（案）」を経て，2003 年に JIS 化され，こ れ以降は統一された試験条件のもと, 材料や調合の違いなどが中性 化抵抗に及ぼす影響を確認するために試験が行われてきている。

また, 昨今, 社会的要請が高い環境配慮や長寿命化対応の高耐久 のコンクリートを新たに開発し,建築物に使用寸るような場合には, 促進中性化試験によって中性化抵抗性を確認し，限られた期間にお ける暴露試験の結果とあわせて中性化の進行が予測されている。

しかし，促進中性化試験における中性化の進行が自然環境での長 期にわたる中性化の進行の何倍の状態に相当するかに関して検討し た研究例えば, 5) は少なく, 促進中性化試験による中性化抵抗性の評価 の多くは相対的なものに留まっている。また, 自然環境下にある実 建築物の中性化の進行の実態を把握するには，比較的長い期間が経
過した構造体からコンクリートコアを採取し, 中性化深さを測定し なければならないが，その結果については一部の報告例例えば，6) 9) を除き，まとまったデータとして十分な公表がなされていないのが 実状である。

そこで, 本研究では, 促進中性化試験の結果から自然環境下にお ける実建築物の中性化の進行を予測するために必要となるデータの 整理・分析と予測手法の提案を行うことを目的とした。

研究内容としては三部構成になっており，まず，促進中性化試験 に関して, これまでは限定された個々の研究成果の報告に留まって いることから, 本研究において既往の促進中性化試験のデータを収 集・整理し，総括的な傾向を検討した。

次に, 自然環境下における実建築物のコンクリートの中性化の進 行に関して定量的な評価を行うために, 実建築物の仕上げがないコ ンクリート基礎梁の地表面から概文高さ $300 \sim 500 \mathrm{~mm}$ の大気に接 している位置から採取したコア供試体を用いて, 中性化の進行の実 態を把握した。

最後に，上記の二つの成果をもとに，促進中性化試験による中性 化と自然環境下における実建築物の中性化の対応に関する検討を行 った。すなわち, 普通ポルトランドセメントを用いた圧縮強度 20 〜 $50 \mathrm{~N} / \mathrm{mm}^{2}$ の範囲にあるコンクリートにより構築された実建築物 の大気に接している基礎梁および上部構造を対象として、自然環境 下におけるコンクリートの中性化の進行を促進中性化試験の結果か ら予測する上での目安となる数值を提示した。
$*$ 宇都宮大学大学院工学研究科 大学院生 $\cdot$ 工修 国立研究開発法人建築研究所 主任研究員

** 宇都宮大学大学院工学研究科 教授・工博
Grad. Stud., Dept. of Architecture, Utsunomiya Univ., M.Eng.

Senior Research Engineer, Building Research Institute

Prof., Dept. of Architecture, Utsunomiya Univ., Dr.Eng. 
2. 促進中性化試験データの統計分析

\section{1 データ収集および分析方法}

データ収集の対象は, 1993 2013 年の過去 20 年間に日本建築学 会構造系論文集, 日本建築学会大会梗概集, コンクリート工学年次 大会論文集等で発表された研究報告とした。この中から, 文献 ${ }^{4}$ に 示された試験方法もしくはJIS A 1153 に準拠して行われた促進中 性化試験による中性化深さ（以下, 促進中性化深さと呼ぶ。）のデー タが示された文献 15 編 10) 24)を取り上げ, 計 68 のデータを収集し た。収集したデータはいずれも普通ポルトランドセメントを用いた コンクリートで水セメント比 W/C は $0.40 \sim 0.80$, 使用混和剤は $\mathrm{AE}$ 減水剤または高性能 $\mathrm{AE}$ 減水剂である。その中でも, W/C について は $0.50 \sim 0.65$ が多く 56 データを占めた。また, 材齢 28 日圧縮強 度 $\sigma_{\mathrm{C} 28}$ については $21.7 \sim 71.1 \mathrm{~N} / \mathrm{mm}^{2}$ の範囲のデータが収集できた が，25 45N/mm²の範囲のものが多かった。表 1 に引用した促進中 性化試験データの範囲と試験条件を, 表 2 に引用した促進中性化試 験データを示す。これらのデータに基づいて, 促進中性化試験によ る中性化速度係数（以下, 促進中性化速度係数と呼ぶ。）について W/C および圧縮強度との関係を中心に整理し，その傾向を把握する。

\section{2 分析結果および考察}

\section{2.1 水セメント比と促進中性化速度係数の関係}

一般に, 促進中性化深さ $\mathrm{d}_{\mathrm{A}}(\mathrm{mm})$ は, 促進期間 $\mathrm{t}_{\mathrm{A}}$ (週) の平方 根に比例する $(\sqrt{\mathrm{t}}$ 則) とされており, 次式で表される。

$$
\mathrm{d}_{\mathrm{A}}=\mathrm{A}_{\mathrm{A}} \sqrt{\mathrm{t}_{\mathrm{A}}}
$$

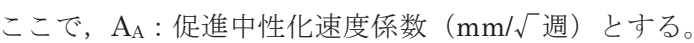

図 1 に, 表 2 のデータの W/C と $\mathrm{A}_{\mathrm{A}}$ の関係を示す。また, 表 3 に, 同一 W/C でデータ数が 5 以上あるものについて, $\mathrm{A}_{\mathrm{A}}$ の平均值, 標 準偏差などを示す。W/C と $\mathrm{A}_{\mathrm{A}}$ の関係については, 直線とする提案 25) や指数関数とする提案 26$)\left(\mathrm{A}_{\mathrm{A}}=\mathrm{me}^{\mathrm{n} \cdot \mathrm{W} / \mathrm{C}}\right.$ ，ここで， $\mathrm{e}$ は自然対数の 底， $\mathrm{m}, \mathrm{n}$ は定数とする。）などがある。本分析データにおいては, ほぼ直線的な関係を示しており，実験值を用いた最小二乗法により 求めた回帰式の式（2）で表すことができる。一方, 指数関数によ る回帰式も図 1 に破線で示寸。指数関数の式は W/C が小さくなる に従って $\mathrm{A}_{\mathrm{A}}$ の勾配も小さくなるという試験結果 26 に基づき提案さ れているが，そこでの試験条件と本論文で収集を行ったデー夕にお ける試験条件を比較すると, 養生期間が 9 週, 促進試験温度が $30^{\circ} \mathrm{C}$ である点に相違がある。この指数関数の式を本データに適用すると, $\mathrm{W} / \mathrm{C}$ が 0.50 より小さい範囲で, 曲線の勾配が緩くなっていくこと に伴い, 次第に実験值と乘離が生じていく傾向を示している。

$$
\mathrm{A}_{\mathrm{A}}=16.2(\mathrm{~W} / \mathrm{C}-0.356)
$$

式（2）は，決定係数 $\mathrm{R}^{2}$ が 0.825 と高い相関性を示している。お およそ W/C が 0.40 以下の範囲では中性化はあまり進行しないこと が見て取れる。図 2 に， $\mathrm{t}_{\mathrm{A}}$ と $\mathrm{d}_{\mathrm{A}}$ の関係について，式（2）の $\mathrm{A}_{\mathrm{A}}$ を 用いた式（1）を W/C 別にグラフ化し，表 2 の実験值をプロットし たものを示す。ある $\mathrm{t}_{\mathrm{A}}$ の時点における個々の $\mathrm{d}_{\mathrm{A}}$ の実験值には試験 体ごとにばらつきが見られるが, $\mathrm{t}_{\mathrm{A}}$ の進行とともに W/C が大きいほ ど $\mathrm{d}_{\mathrm{A}}$ が大きく増加する傾向を概ね良く捉えることができている。 なお, 同一W/C の条件においても, $\mathrm{A}_{\mathrm{A}}$ に違いが出る要因として, 骨材や混和剤などの使用材料の違い, 空気量, 単位水量や単位セメ

\begin{tabular}{|c|c|}
\hline 項 目 & 水 準 \\
\hline セメントの種類 & 普通ポルトランドセメント \\
\hline 水セメント比 W/C & $0.40 \sim 0.80$ \\
\hline スランプ $(\mathrm{cm})$ & $2.5 \sim 20.5$ \\
\hline 空気量（\%） & $3.7 \sim 6.0$ \\
\hline 使用混和剂 & $\mathrm{AE}$ 減水剂, 高性能 $\mathrm{AE}$ 減水剂 \\
\hline $20^{\circ} \mathrm{C}$ 水中養生期間（週） & 4 \\
\hline 促進中性化期間（週） & $1 \sim 26$ \\
\hline 温度 $\left({ }^{\circ} \mathrm{C}\right)$ & $20 \pm 2$ \\
\hline 相対湿度（\%) & $60 \pm 5$ \\
\hline 二酸化炭素濃度（\%) & $5 \pm 0.2$ \\
\hline 収集したデータ数 & 68 (文献 15 編） \\
\hline 材齢 28 日圧縮強度のあるデータ数 & 56 \\
\hline
\end{tabular}

表 1 引用した促進中性化試験データの範囲

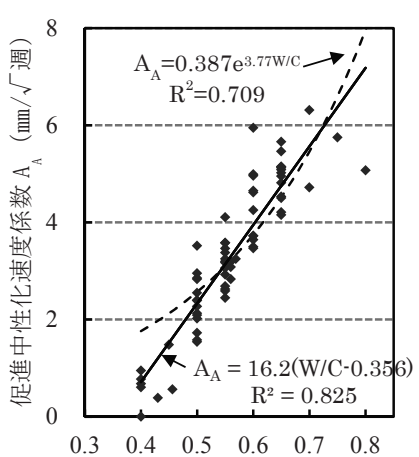

水セメント比 $\mathrm{W} / \mathrm{C}$

表 3 W/C ごとの促進中性化速度 係数の実験値

\begin{tabular}{l|l|l|l|l|l|}
\hline $\mathrm{W} / \mathrm{C}$ & 0.40 & 0.50 & 0.55 & 0.60 & 0.65 \\
\hline
\end{tabular} \begin{tabular}{|c|c|c|c|c|c|}
\hline デー多数 & 5 & 14 & 14 & 11 & 13 \\
\hline
\end{tabular} \begin{tabular}{|c|c|c|c|c|c|} 
文献数 & 4 & 8 & 4 & 7 & 4 \\
\hline
\end{tabular}

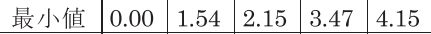
\begin{tabular}{l|l|l|l|l|l|} 
最大値 & 0.68 & 3.52 & 4.11 & 5.95 & 5.66 \\
\hline
\end{tabular}

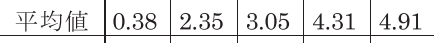

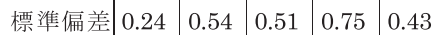
\begin{tabular}{l|l|l|l|l|l|l|} 
変動係数 & 0.65 & 0.23 & 0.17 & 0.17 & 0.09 \\
\hline
\end{tabular}

(中性化速度係数の単位は $\mathrm{mm} / \mathrm{N}$ 週 で, 表にはデータ数が 5 以上の W/C のみ示した。)

図 1 W/C と促進中性化速度係数 の関係

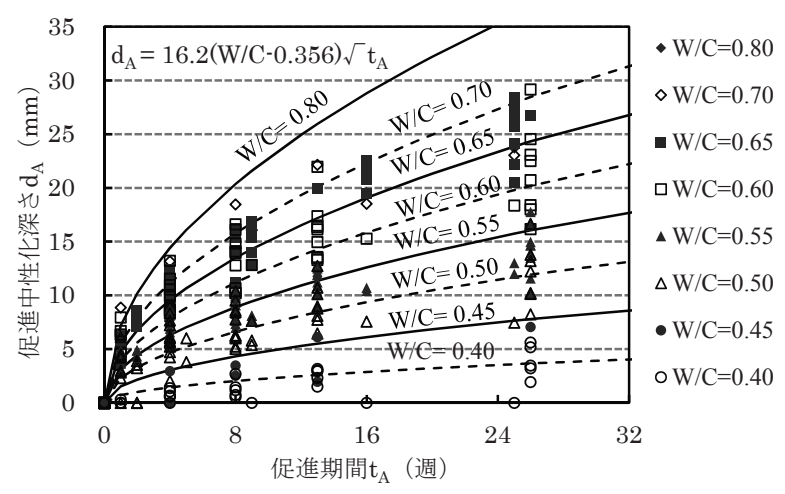

図 $2 \mathrm{~W} / \mathrm{C}$ 比別の促進期間と促進中性化深さの関係

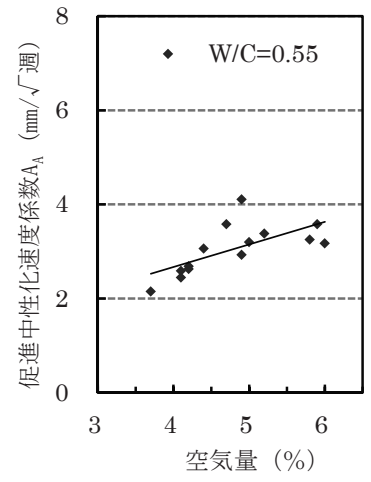

図 3 空気量と促進中性化 速度係数の関係

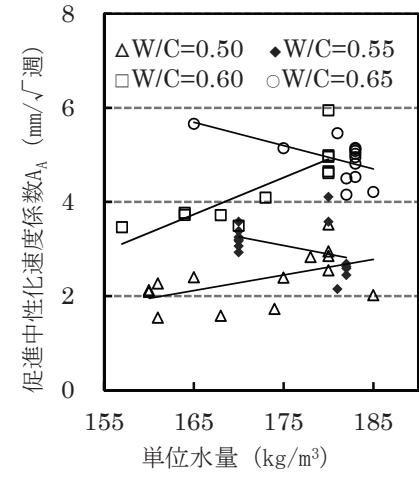

図 4 単位水量と促進中性化 速度係数の関係 
表2 引用した促進中性化試験データ

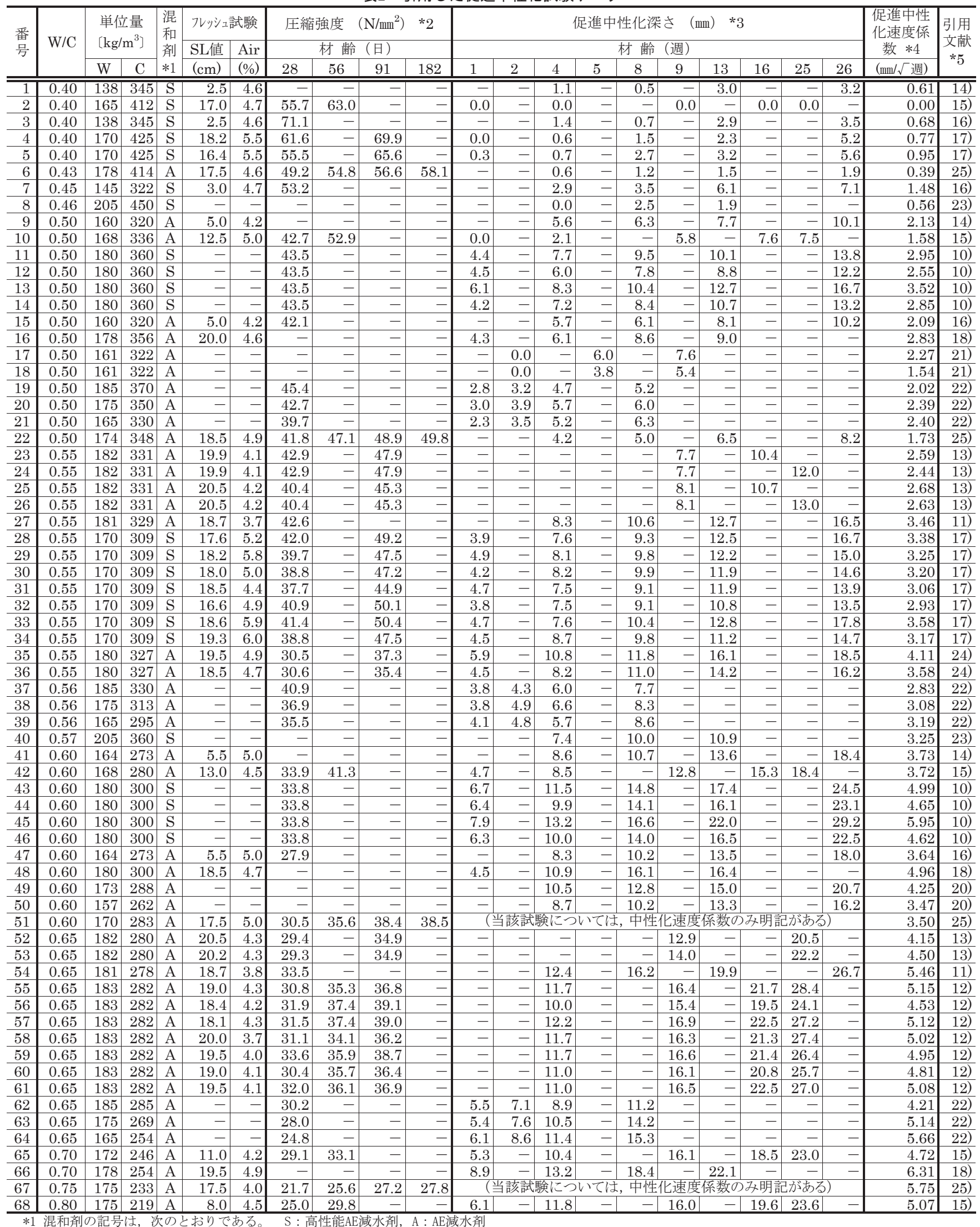

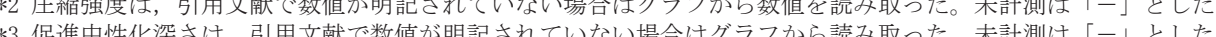

*4 促進中性化速度係数は, 引用文献で数值が明記されていない場合は, 表中の「促進中性化深さ」の数值から最小二乗法による回帰式で求めた。

*5 引用文献の番号は，巻末に示寸参考文献番号に対応している。 
ント量などの調合の違い, 締固めの差などコンクリート供試体の製 作上の要因などが考えられる。ここに, 表 2 のデータのうち同一 $\mathrm{W} / \mathrm{C}$ の条件で比較検証が可能である水準として, $\mathrm{A}_{\mathrm{A}}$ と, フレッシ ユ試験の空気量および単位水量がある。空気量はデータ数で 10 以 上あり, 比較的広い範囲のデータがある W/C が 0.55 に限定して図 3 に示寸。空気量が $3.7 \%$ から $6.0 \%$ に増加寸るにつれて $\mathrm{A}_{\mathrm{A}}$ も大き くなる傾向が見られる。単位水量はデータ数で 10 以上ある $\mathrm{W} / \mathrm{C}$ が $0.50,0.55,0.60$ および 0.65 について図 4 に示寸。単位水量の増 加に伴い $\mathrm{A}_{\mathrm{A}}$ も大きくなる傾向が見られるが, W/C が 0.55 および 0.65 では負の相関を示しており， $\mathrm{A}_{\mathrm{A}}$ と単位水量の関係について本 分析データからは統一的な傾向を確認することはできなかった。文 献 15 編からデータを引用し， $\mathrm{A}_{\mathrm{A}}$ に若干のばらつきが見られるが, 本分析データの促進環境条件は一定の範囲にあり, また養生条件は 同一であることから, 式 (2) は試験水準の範囲内における促進中 性化の平均的な傾向を示すものとして妥当であると考えられる。

\subsection{2 圧縮強度と促進中性化速度係数の関係}

中性化速度係数 $\mathrm{A}$ は, コンクリートの圧縮強度 $\sigma_{\mathrm{C}}$ と相関性が高 いことがこれまでにも多く報告されている。 $\mathrm{A}$ と $\sigma$ の関倸について は, 式（3）に示すような $\sigma_{\mathrm{C}}$ に反比例するという提案 27)や式 (4) に示すような $\sigma_{\mathrm{C}}$ の平方根に反比例するという提案 28$)$ な゙゙がある。

$$
\begin{aligned}
& \mathrm{A}=\mathrm{a}\left(1 / \sigma_{C}-\mathrm{b}\right) \\
& \mathrm{A}=\mathrm{a}\left(1 / \sqrt{\sigma_{C}}-\mathrm{b}\right)
\end{aligned}
$$

ここで， $\mathrm{a}, \mathrm{b}$ : 定数とする。

図 5 に, 表 2 のデータの材齢 28 日圧縮強度 $\sigma_{\mathrm{C} 28}\left(\mathrm{~N} / \mathrm{mm}^{2}\right)$ と $\mathrm{A}_{\mathrm{A}}$ の関係を示す。また, 表 4 に，25〜 $45 \mathrm{~N} / \mathrm{mm}^{2}$ まで $5 \mathrm{~N} / \mathrm{mm}^{2}$ ごとに $\sigma_{\mathrm{C} 28}$ を区分した範囲における $\mathrm{A}_{\mathrm{A}}$ の平均值, 標準偏差などを示す。 ここでは, 式 (3) に比べて, 式（4）の関係に基づいて実験值を用 いた最小二乗法により回帰式を求めた式（5）の方が， $50 \mathrm{~N} / \mathrm{mm}^{2}$ 付 近から $\mathrm{A}_{\mathrm{A}}$ の実験值が 0 に近くなる傾向と乘離が少なく, 比較的高 い相関を示している。なお, 式 (5) で $\mathrm{A}_{\mathrm{A}}$ が 0 になるのは 計算上, $77 \mathrm{~N} / \mathrm{mm}^{2}$ 付近である。

$$
\mathrm{A}_{\mathrm{A}}=67.2\left(1 / \sqrt{\sigma_{\mathrm{c} 28}}-0.114\right)
$$

図 6 に， $\mathrm{t}_{\mathrm{A}}$ と $\mathrm{d}_{\mathrm{A}}$ の関係について式 (5) を б $\mathrm{C}_{2} 8$ 別にグラフ化し, 表 2 の実験值をプロットしたものを示す。傾向としては, W/C との 関係を示した図 2 とほぼ同様の傾向で, $\mathrm{t}_{\mathrm{A}}$ の進行とともに $\sigma_{\mathrm{C} 28}$ が小 さいほど $\mathrm{d}_{\mathrm{A}}$ が大きく増加する傾向にあることを概脪く捉えるこ とができている。ただし, 表 4 で示すように, $25 \sim 30 \mathrm{~N} / \mathrm{mm}^{2}$ と 30 $\sim 35 \mathrm{~N} / \mathrm{mm}^{2}$ の両区間における $\mathrm{A}_{\mathrm{A}}$ の平均值がほぼ同じであるように, W/C の場合に比べて, $\sigma_{\mathrm{C} 28}$ の実験值とその回帰式との関係にはばら つきが見られる。また, $50 \mathrm{~N} / \mathrm{mm}^{2}$ 付近から $\mathrm{A}_{\mathrm{A}}$ の実験值がほぼ 0 の データが見られるが， $45 \sim 60 \mathrm{~N} / \mathrm{mm}^{2}$ にかけてのデータ数は十分で はない。 $\mathrm{A}_{\mathrm{A}}$ と $\sigma_{\mathrm{C}}$ の関係を総括的に把握するうえで, 式 (5) の適用 性と精度の向上には, この範囲におけるデータの補完が必要である。

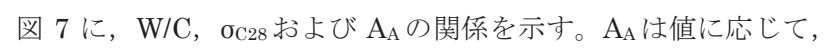
図中の点を分類して示している。 $\mathrm{W} / \mathrm{C}$ が大きく, $\sigma_{\mathrm{C} 28}$ が小さい範囲 に $\mathrm{A}_{\mathrm{A}}$ の值が大きな点がプロットされている傾向がわかる。

一般的に $\sigma_{\mathrm{C}}$ と $\mathrm{A}_{\mathrm{A}}$ の関係を表す際には, 標準養生供試体の材齢 28 日の圧縮強度 $\sigma_{\mathrm{C} 28}$ を用いることが多いが, 材齢 91 日の圧縮強度 $\sigma_{\mathrm{C} 91}$ と $\mathrm{A}_{\mathrm{A}}$ の関係も検討した。図 8 に, бC 91 と $\mathrm{A}_{\mathrm{A}}$ の関係を示す。ここで

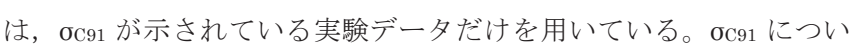
ても式（4）の関係に基づいて回帰式を求めた。また， $\sigma_{\mathrm{C} 28}$ による式 （5）を破線であわせて示す。 $\sigma_{\mathrm{C} 91}$ の平均值（データ数 28）が 44.1 $\mathrm{N} / \mathrm{mm}^{2}$ であるのに対して, $\sigma_{\mathrm{C} 28}$ の平均值（データ数 56）は 38.2 $\mathrm{N} / \mathrm{mm}^{2}$, このうち $\sigma_{\mathrm{C} 91}$ の結果もある $\sigma_{\mathrm{C} 28}$ の平均值（データ数 28） は $37.4 \mathrm{~N} / \mathrm{mm}^{2}$ であるから平均して $18 \%$ 程度, 強度が上昇している。 これにより回帰式は全体的に図の右側に移動するとともに，曲線の 勾配も若干高くなっている。 $\sigma_{\mathrm{C} 28}$ が大きい供試体ほど $\sigma_{\mathrm{C} 91}$ の強度上 昇率は比較的小さくなることを示しているがその差は極めてわずか である。

以上，既往の促進中性化試験のデータを整理し， $\mathrm{A}_{\mathrm{A}}$ と W/C およ び $\sigma_{\mathrm{C}}$ の関係を中心に総括的な傾向を検討した。

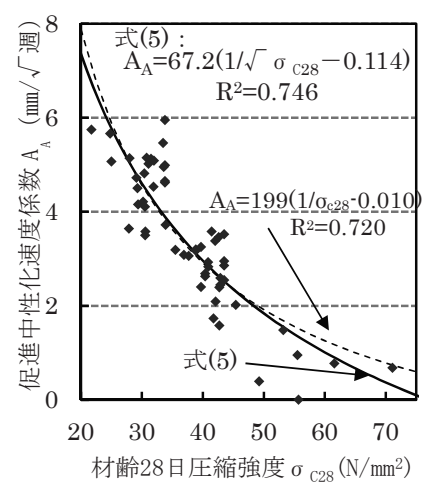

図 5 材齢 28 日圧縮強度と促進 中性化速度係数の関係
表 4 材齢 28 日圧縮強度にお

\begin{tabular}{|c|c|c|c|c|}
\hline \multirow{3}{*}{$\begin{array}{c}\sigma_{\mathrm{C} 28} \\
\left(\mathrm{~N} / \mathrm{mm}^{2}\right)\end{array}$} & 25 & 30 & 35 & 40 \\
\hline & $\sim$ & $\sim$ & $\sim$ & $\sim$ \\
\hline & 30 & 35 & 40 & 45 \\
\hline デーー夕数 & $\overline{66}$ & 17 & $\overline{7}$ & 17 \\
\hline 最小值 & 3.77 & 3.50 & 2.40 & 1.58 \\
\hline 最大値 & 5.14 & 5.95 & 3.25 & 3.58 \\
\hline 平均値 & 4.56 & 4.67 & 3.05 & 2.64 \\
\hline 標淮偏差 & 0.49 & 0.65 & 0.27 & 0.55 \\
\hline 変動係数 & 0.11 & 0.14 & 0.09 & 0.21 \\
\hline
\end{tabular}
ける強度区分ごとの促進中 性化速度係数の実験值

(中性化速度係数の単位はmm $/ \sqrt{\text { 週 }}$ で, 表にはデータ数が 5 以上の強 度区分のみ示した。）

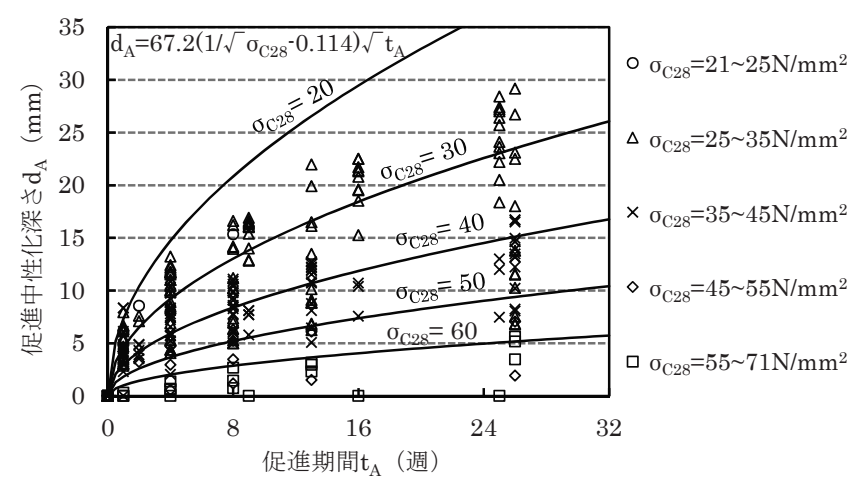

図 6 材齢 28 日圧縮強度別の促進期間と促進中性化深さの関係

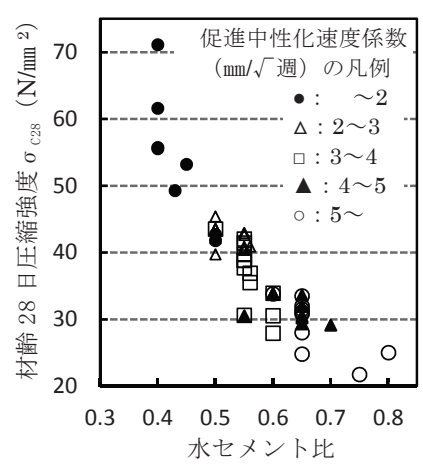

図 7 W/C, 材齢 28 日圧縮強度お よび促進中性化速度係数の関係

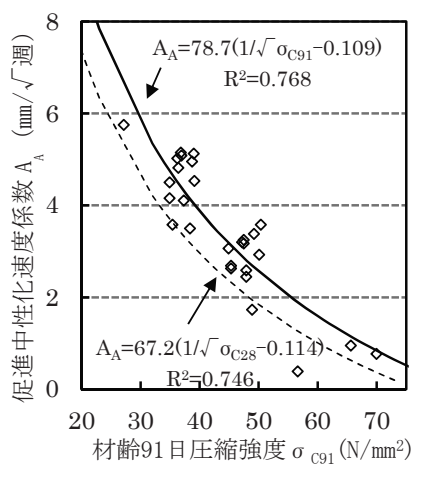

図 8 材齢 91 日圧縮強度と促進 中性化速度係数の関係 
3. 実建築物における中性化データの統計分析

3. 1 分析対象および分析方法

\section{1.1 分析対象建築物の概要}

本研究で分析対象とした実建築物およびコンクリートコア供試体 の概要を表 5 に示す。建築物は, 関東・近畿・東海地域にある $2 \sim 5$ 階建ての鉄筋コンクリート造集合住宅である。その多くが整形な平 面・立面形状で，南面にバルコニー，北面に階段室があり，建築物 の長さに相違があるがほぼ類似の形状である。当該建築物の大規模 修繕工事を行う際の 2003〜2010 年にかけて, コンクリート躯体の 健全性を確認することを目的にコア供試体を採取し, 圧縮強度や中 性化深さが測定されている。その中から, 屋外に露出している基礎 梁上端部分でコンクリート表面に仕上げ材が施されていない, 打放 し部分で採取したコア供試体のデータを抽出した。ここで，打放し の基礎梁に限定したのは, 本分析の目的が促進中性化試験と自然環 境におけるコンクリートの中性化の進行を対比するための基礎デー タの収集であり, まずは仕上げ材や補修材の塗重祇の違いによる中 性化抑制効果の違いや屋内での人間活動状況の違いによる $\mathrm{CO}_{2}$ 濃 度の違いなどの不確定要素を取り除いた条件で検討するためである。

これらを踏まえて抽出した分析対象建築物は 1210 棟あり, 基礎 梁から採取したコア供試体は各棟 1 本であったため, 分析対象コア 供試体本数は 1210 本である。竣工年は図 9 に示寸 1964 1994 年, 中性化深さ測定時の竣工からの経過年数は図 10 に示す $15 \sim 44$ 年で, この経過年数の 15 年目と 34 年目前後にピークが見られるのは, 1 回目および 2 回目の大規模修繥工事の多くがこの周期で行われたこ とによる。

\section{1.2 コア供試体の採取位置および採取方法の状況}

コア供試体の採取位置は, 図 11 に示すように概ね地表面より高 さ $500 \mathrm{~mm}$ 程度屋外に露出している基礎梁からコアドリルで採取す る作業空間を考慮すると低くても地表面から高さ $300 \mathrm{~mm}$ 程度にな る。採取位置の上部に庇がある場合でも $2 \mathrm{~m}$ 以上は離れるため, 直 接の雨がかりになる位置である。また, 地表面から高さ $300 \mathrm{~mm}$ 程 度の部位には，地表面での雨の跳ね返りがかかる可能性は低い299。

コア採取は，原則，屋外側から作業して部材を貫通するコアを採 取しているが，部材断面内で鉄筋と干渉した場合などは，強度試験 に必要と寸るコア供試体長さが確保できているのであれば, 途中で 折り取って, 中性化の測定は片面のみで行われている。

貫通コアにおける採取側先端は, そのほとんどが床下に該当する。 床下地表面は, 土, 敷砂利およびコンクリートなど建築物ごとに様々 である。床下の環境条件は, 基礎梁にある換気口から外気の流入が あるため, $\mathrm{CO}_{2}$ 濃度は屋外と同じとみなせるが，雨がかりと日射は ない。また，屋外に比べて床下は，相対湿度が $6 \sim 12 \%$ 高く, 月平 均で $90 \%$ 近くになる場合もあり結露も生ずるという報告例 30 ), 31)が ある。日射もないので, 湿潤環境は保たれ易い条件にあると言える。

方位別のコア供試体本数は, 表 5 に示すように西面が中心で, 南 面および北面は少ない。これは，一般的に中性化は南面>西面>東 面>北面の順に進行が速い6) とされており, 本研究で分析対象とし たコア供試体の本来の採取目的が建築物個別に行った健全性調査で あったため, 比較的中性化の進行が速いとされる西面を中心に採取 方位が選定されていたことによる。また, 南面の本数が少ない理由 は, 通常, 集合住宅の南面にはバルコニーがあることが多く, バル
コニーが取付く基礎梁でのコア採取作業が困難なためである。なお， 対象建築物のほとんどが，離棟間隔を確保して配置される団地内の 建築物であるため, 東面・西面・南面の屋外に露出している基礎梁 のコア採取表面は基本的に日射面と見なすことができる。

\section{1.3 調查方法}

コンクリートの圧縮強度試験方法は，JIS A 1107 に準拠されてい る。中性化深さの測定は，JIS A 1152 に準拠されているが，コア供 試体は圧縮強度試験用と兼用しているため，コア採取後にコンクリ

表 5 分析対象とした建築物およびコンクリートコア供試体

\begin{tabular}{|c|c|}
\hline 項 目 & 水 準 \\
\hline 構造種別・用途 & 鉄筋コンクリート造集合住宅 \\
\hline 階 数 & 地上 2〜5 階 \\
\hline 棟 数 & 1210 棟 \\
\hline 地 域 & $\begin{array}{c}\text { 関東（東京，千葉，埼玉，神奈川，茨城）, } \\
\text { 近畿（大阪，京都，奈良，兵庫）， } \\
\text { 東海（愛知，三重） }\end{array}$ \\
\hline 竣工年 & $1964 \sim 1994$ 年 \\
\hline 試験時の経過年数 & $15 \sim 44$ 年 \\
\hline 設計基準強度 & $16.5,18,21\left(\mathrm{~N} / \mathrm{mm}^{2}\right){ }^{*} 1$ \\
\hline コンクリートの種類 & 普通コンクリート \\
\hline セメントの種類 & 普通ポルトランドセメント \\
\hline コア採取部位 & 屋外に露出している基礎梁上端部分 \\
\hline 仕上げ材 & 基礎梁両側面ともになし（打放し） \\
\hline コア供試体本数 & 1210 本 \\
\hline 方 位 & $\begin{array}{c}\text { 東面 }(140 \text { 本 }) \text {, 西面 }(813 \text { 本 }) \text {, 南面 }(7 \text { 本 }) \text {, } \\
\text { 北面 }(21 \text { 本 }) ， \text { 不明 }(229 \text { 本 })\end{array}$ \\
\hline 環境条件 & $\begin{array}{c}\text { 屋外 (東・西・南：雨がかりあり・日射あり， } \\
\text { 北：雨がかりあり・日射なし） } \\
\text { 床下 (雨ががなし・日射なし・多湿) }\end{array}$ \\
\hline 分析データ数 $\mathrm{n}$ & 屋外 $(1210$ データ $)$, 㦿下 $(673$ データ $)$ \\
\hline
\end{tabular}

（*1＼cjkstart建設時は kg/cm²であるが，変換係数 10 で SI 単位表記にした。）

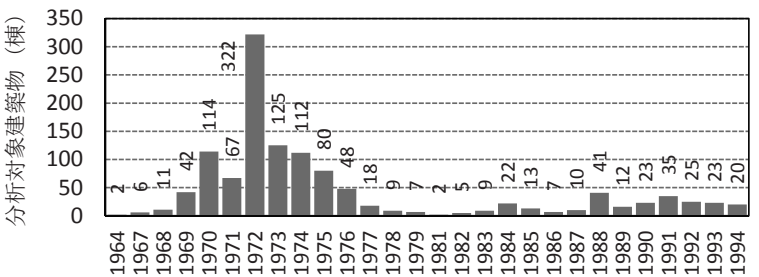
竣工年（西暦年）

図 9 竣工年の分布

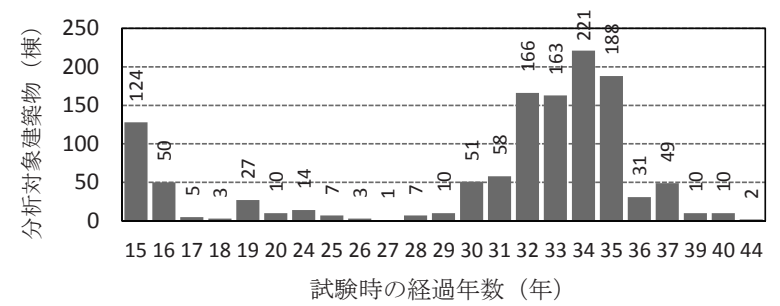

図 10 試験時の経過年数の分布

※コア採取位置の例を図中矢印セで示す

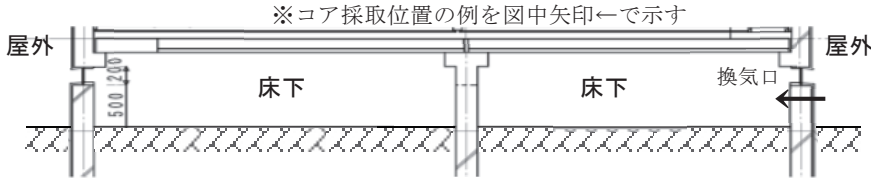

図 11 コア採取位置の模式図 
ート表面からの距離をマーキングしてから圧縮強度試験が行われ, コア供試体を割裂させた後に，フェノールフタレイン $1 \%$ 溶液を割 裂面に噴霧して測定されている。コア 1 本あたりの中性化深さのデ 一夕は, 貫通コアの場合で屋外側と床下側の 2 データ, 折り取りコ アの場合で屋外側の 1 データである。なお, 分析対象とした建築物 の建設時におけるコンクリートの調合計画書や標準養生供試体の圧 縮強度試験結果などは残されていなかったため, W/C や $\sigma_{\mathrm{C} 28}$ は不明 であるが，使用したセメントの種類は設計図書において普通ポルト ランドセメントであることを確認している。

\section{1.4 分析方法}

\section{1 ）環境条件，方位および地域別の中性化速度係数}

一般に，自然環境におけるコンクリートの中性化深さ $\mathrm{d}_{\mathrm{N}}(\mathrm{mm})$ は期間 $\mathrm{t}_{\mathrm{N}}$ (年) の平方根に比例するとされており, 次式で表される。

$$
\mathrm{d}_{\mathrm{N}}=\mathrm{A}_{\mathrm{N}} \sqrt{\mathrm{t}_{\mathrm{N}}}
$$

ここで, $A_{N}$ ：自然環境下の中性化速度係数 $(\mathrm{mm} / \sqrt{ }$ 年 $)$ とする。 測定した $\mathrm{d}_{\mathrm{N}}$ と竣工から中性化深さ測定時までの $\mathrm{t}_{\mathrm{N}}$ を用いてコア ごとに求めた各 $\mathrm{A}_{\mathrm{N}}$ を, 環境条件 (屋外・床下), 方位（東・西・南・ 北）および地域（関東・近畿・東海）の各組合せで区分し, 最小二 乗法による回帰式の定数としてそれぞれ $\mathrm{A}_{\mathrm{N}}$ を算出した。

\section{2 ) 圧縮強度と中性化速度係数の関係}

コアごとに求めた $A_{\mathrm{N}}$ と当該コアにおける圧縮強度 $\sigma_{\mathrm{CN}}\left(\mathrm{N} / \mathrm{mm}^{2}\right)$ を用いて, 式（3）および式（4）の定数 $\mathrm{a}, \mathrm{b}$ を最小二乗法による 回帰式でそれぞれ算出した。また, 屋外暴露試験の結果に基づく既 往式との比較を行った。

\section{2 分析結果および考察}

\section{2.1 環境条件，方位および地域別の中性化速度係数}

表 6 に, 環境条件 (屋外・床下), 方位（東・西・南・北）およ び地域（関東・近畿・東海）の各組合せによる区分の $\mathrm{A}_{\mathrm{N}}$ とそのデ 一夕数 $\mathrm{n}$ を示す。また, 西面・全地域の $\mathrm{A}_{\mathrm{N}}$ を 1 として基準化した 場合のそれぞれの $\mathrm{A}_{\mathrm{N}}$ に対する倍率を $\beta$ として示す。ここで, 地域 と方位を区分しないで取り扱った場合は, それぞれ全地域, 全方位 と表記した。図 12 に, 環境条件および方位の各組合せによる区分 の $\mathrm{t}_{\mathrm{N}}$ と $\mathrm{d}_{\mathrm{N}}$ のデータをプロットし, それぞれ回帰式により求めた $\mathrm{A}_{\mathrm{N}}$ を示す。全方位のデータには, 方位が不明なデータも含まれている。 また, 南面のデー夕数は屋外・全地域で 7 , 床下・全地域で 3 と少 ないが，参考として取り上げた。

図 12 に示すように, 各区分とも全体的に $\mathrm{t}_{\mathrm{N}}$ の進行に伴い, $\mathrm{d}_{\mathrm{N}}$ が 大きくなる傾向が現れている。 $\mathrm{t}_{\mathrm{N}}$ は 15 年目と 34 年目前後のデータ 数が多いが, $\mathrm{d}_{\mathrm{N}}$ のばらつきの幅は 34 年目前後の方が大きい。 $\mathrm{A}_{\mathrm{N}}$ は, 1.35〜5.53 の幅がある。環境条件の違いによる影響は明瞭に表われ ており, 表 6 に示すように, 近畿の東面における屋外と床下の $\mathrm{A}_{\mathrm{N}}$ がほぼ同じであることを除けば,残りは全ての地域・方位において, 屋外に比べて床下の $\mathrm{A}_{\mathrm{N}}$ の方が小さい。デー夕数が十分にある西面・ 全地域で見ると, 床下の $\mathrm{A}_{\mathrm{N}}$ は屋外に対して $0.71(=3.00 / 4.25)$ 倍, 東面・全地域では 0.79 (=3.08/3.91) 倍である。また, 貫通コア 673 本における, 同一コアでの屋外と床下の $\mathrm{A}_{\mathrm{N}}$ の関係を図 14 に, 屋外 に対する床下の $\mathrm{A}_{\mathrm{N}}$ の比率の度数分布を図 15 に示す。広い範囲での ばらつきは見られるが, 床下の $\mathrm{A}_{\mathrm{N}}$ が屋外の $\mathrm{A}_{\mathrm{N}}$ を下回っているコア 本数の割合は $80 \%$ 程度になり, 屋外に対する床下の $\mathrm{A}_{\mathrm{N}}$ の比率は平
均で 0.67 倍程度である。床下の環境条件は，3.1.2 で述べたとお り, 直接の雨がかりにはならないが, 外気に比べて湿度は高くなる。 このコンクリート表面における雰囲気の湿度の差が中性化の進行に 影響を与えていると考えられる。

湿度の影響に関しては, 阿部らは促進中性化試験法の評価におい て次式を提案 ${ }^{3)}$ している。

$$
\mathrm{A}_{\mathrm{Hu}}=\mathrm{Hu}(100-\mathrm{Hu})(140-\mathrm{Hu}) / 192000
$$

ここで， $A_{\mathrm{Hu}}$ ：湿度の影響係数で相対湿度 $60 \%$ の場合に対する中 性化速度係数の比, $\mathrm{H}_{\mathrm{u}}$ : 相対湿度（\%R.H.）とする。

日本建築学会の耐久設計施工指針 2)においても，建築物の耐久設 計を行う際の中性化速度係数を算出するうえで，上記影響係数の考 えが採用されている。ここで，式(7)を適用して，表 6 の分析におい て最もデータ数が多い関東・西面における, 屋外に対する床下の $\mathrm{A}_{\mathrm{N}}$ の比率 $0.65(=2.84 / 4.34)$ 倍に相当する湿度条件を検討する。屋外 の $\mathrm{H}_{\mathrm{u}}$ を東京の年平均相対湿度である $63 \%{ }^{2)}$ とすると $\mathrm{A}_{\mathrm{Hu}}$ は 0.93 に なり,この数值に本データでの床下との比率である 0.65 を乗じて求 めた 0.60 が床下の $\mathrm{A}_{\mathrm{Hu}}$ に相当する。床下の $\mathrm{H}_{\mathrm{u}}$ をこの $\mathrm{A}_{\mathrm{Hu}}$ を用いて 式(7)から逆算的に求めると $76 \%$ 程度になり, 屋外に比べて $13 \%$ 程 度高い環境ということになる。この $\mathrm{H}_{\mathrm{u}}$ の差は，屋外と床下におけ る $\mathrm{H}_{\mathrm{u}}$ の実測報告例 30 )，31)の 6 $12 \%$ とも概衫対応しており，本分析 における屋外と床下の $\mathrm{A}_{\mathrm{N}}$ の違いから，主に湿度環境の違いが $\mathrm{A}_{\mathrm{N}} に$ 与えている影響を推定することができる。

方位に関しては, 表 6 に示すように, 屋外・全地域において, 南 面 >西面 >東面 $>$ 北面の順に $\mathrm{A}_{\mathrm{N}}$ が大きくなり，全地域で見れば $\mathrm{A}_{\mathrm{N}}$ の範囲は 5.53 3.31 で 1.67 倍の幅がある。データ数が十分にある 西面と東面における $\mathrm{A}_{\mathrm{N}}$ の比率は $1.09(=4.25 / 3.91)$ 倍で, 既往文 献の報告例 ${ }^{6}$ における 1.22 倍より小さかった。この理由として, 本 分析に用いたコア供試体の採取位置が地表面から概放高さ 300 $500 \mathrm{~mm}$ の範囲にあるため, 採取位置が上階のデータがある場合に 比べると, 日射による方位別のコンクリートの乾燥状態の違いの差 が小さい可能性が考えられる。一方, 床下では, 南面 $\fallingdotseq$ 西面 $\fallingdotseq$ 東面 >北面であるため, 日射量の違いが屋外の方位別の $\mathrm{A}_{\mathrm{N}}$ に影響を及 ぼしていることが伺える。なお，北面のみ $\mathrm{A}_{\mathrm{N}}$ が小さいのは，床下 では相対的に北面の湿潤環境が高いが，東面・南面・西面の間では 比較的その差が小さいからと考えられる。

地域に関しては，表 6 に示寸ように，屋外・西面と屋外・東面で は, 関東 > 近畿 > 東海の順に $\mathrm{A}_{\mathrm{N}}$ が大きくなっている。 $\mathrm{A}_{\mathrm{N}}$ の範囲は, 屋外・西面において 4.34 4.00 で 1.09 倍, 屋外・東面において 4.07 ～3.60 で 1.13 倍の幅がある。一方で, 床下・西面と床下・東面で は, 近畿 >東海 >関東の順に $\mathrm{A}_{\mathrm{N}}$ が大きくなっており, 関東では床 下に比べると屋外の中性化の進行が相対的に速い傾向である。

\subsection{2 圧縮強度と中性化速度係数の関係}

表 7 に, 表 6 の区分に対応した $\sigma \mathrm{CN}$ の平均值, 標準偏差およびコ ア本数 $\mathrm{n}$ を示す。なお, 床下の中性化深さの測定はコア全数ではな いが，屋外は全数で測定しているので，屋外の欄に記載している圧 縮強度の数值がコア全数を代表する值である。図 13 に, コアごと に求めた $A_{\mathrm{N}}$ と当該コアにおける圧縮強度 $\sigma_{\mathrm{CN}}\left(\mathrm{N} / \mathrm{mm}^{2}\right)$ を環境条 件別および方位別の図にプロットし， $\mathrm{A}_{\mathrm{N}}$ と $\sigma \mathrm{CN}$ の関係式として， 式（3）および式（4）の定数 a, b を最小二乗法の回帰式でそれぞ 
表 6 環境条件，方位および地域の各組合せによる区分の各中性化速度係数 $A_{N}(\mathrm{~mm} / \sqrt{ }$ 週）

\begin{tabular}{|c|c|c|c|c|c|c|c|c|c|c|c|c|c|c|c|c|}
\hline & \multicolumn{3}{|c|}{ 全方位 ${ }^{* 1}$} & \multicolumn{3}{|c|}{ 東 面 } & \multicolumn{3}{|c|}{ 西 面 } & \multicolumn{3}{|c|}{ 南 面 } & \multicolumn{3}{|c|}{ 北 面 } \\
\hline & & $\mathrm{A}_{N}$ & $\beta^{* 2}$ & $\mathrm{n}$ & $\mathrm{A}_{\mathrm{N}}$ & $\beta^{* 2}$ & $\mathrm{n}$ & $\mathrm{A}_{N}$ & $\beta^{* 2}$ & $\mathrm{n}$ & $\mathrm{A}_{\mathrm{N}}$ & $\beta^{* 2}$ & $\mathrm{n}$ & $\mathrm{A}_{N}$ & $\beta^{* 2}$ & $\mathrm{n}$ \\
\hline \multirow[b]{2}{*}{ 屋 } & 全地域 & 4.16 & 0.98 & 1210 & 3.91 & 0.92 & 140 & 4.25 & 1 & 813 & 5.53 & 1.30 & 7 & $\begin{array}{l}3.31 \\
\end{array}$ & 0.78 & 21 \\
\hline & 関東 & 4.44 & 1.04 & 600 & 4.07 & 0.96 & 74 & 4.34 & 1.02 & 419 & 5.40 & 1.27 & 5 & 4.72 & 1.11 & 5 \\
\hline \multirow{2}{*}{ 外 } & 近畿 & 3.86 & 0.91 & 511 & 3.75 & 0.88 & 55 & 4.20 & 0.99 & 307 & 4.29 & - & 1 & 2.61 & 0.61 & 16 \\
\hline & 東海 & 3.99 & 0.94 & 99 & 3.60 & 0.85 & 11 & 4.00 & 0.94 & 87 & 6.79 & - & 1 & - & - & 0 \\
\hline \multirow{2}{*}{ 床 } & 全地域 & 2.89 & 0.68 & 673 & 3.08 & 0.72 & 119 & 3.00 & 0.71 & 363 & 3.00 & 0.71 & 3 & 1.35 & 0.32 & 19 \\
\hline & 関東 & 2.80 & 0.66 & 220 & 2.47 & 0.58 & 55 & 2.84 & 0.67 & 83 & 2.25 & - & 1 & 0.34 & 0.08 & 3 \\
\hline \multirow{2}{*}{ 下 } & 近畿 & 2.93 & 0.69 & 367 & 3.76 & 0.88 & 54 & 3.10 & 0.73 & 205 & 1.34 & - & 1 & 1.65 & 0.39 & 16 \\
\hline & 東海 & 2.97 & 0.70 & 86 & 3.24 & 0.76 & 10 & 2.91 & 0.68 & 75 & 4.67 & - & 1 & - & - & 0 \\
\hline
\end{tabular}

表 7 環境条件, 方位および地域の各組合せによる区分の各圧縮強度 $\sigma_{\mathrm{CN}}\left(\mathrm{N} / \mathrm{mm}^{2}\right)$

\begin{tabular}{|c|c|c|c|c|c|c|c|c|c|c|c|c|c|c|c|c|}
\hline & \multicolumn{3}{|c|}{ 全方位 ${ }^{* 1}$} & \multicolumn{3}{|c|}{ 東 面 } & \multicolumn{3}{|c|}{ 西 面 } & \multicolumn{3}{|c|}{ 南 面 } & \multicolumn{3}{|c|}{ 北 面 } \\
\hline & & $\sigma_{\mathrm{CN}}$ 平均値 & 標淮偏差 & $\mathrm{n}$ & $\sigma_{\mathrm{CN}}$ 平均值 & 標淮偏差 & $\mathrm{n}$ & $\sigma_{\mathrm{CN}}$ 平均値 & 標準偏差 & $\mathrm{n}$ & $\sigma_{\mathrm{CV}}$ 平均值 & 標準偏差 & $\mathrm{n}$ & $\sigma_{\mathrm{CN}}$ 平均值 & 標準偏差 & $\mathrm{n}$ \\
\hline \multirow{2}{*}{ 屋 } & 全地域 & 31.2 & "6.96 & 1210 & 31.6 & "6.90 & 140 & 31.2 & 7.00 & 813 & 29.6 & 5.50 & 7 & 34.5 & 5.60 & 21 \\
\hline & 関東 & 30.8 & 6.72 & 600 & 31.8 & 7.00 & 74 & 31.3 & 6.80 & 419 & 29.5 & 2.30 & 5 & 27.6 & 4.90 & 5 \\
\hline 外 & 東海 & 29.3 & 7.90 & 99 & 27.5 & 3.30 & 11 & 29.6 & 8.30 & 87 & 20.0 & - & 1 & - & - & 0 \\
\hline \multirow{2}{*}{ 床 } & 全地域 & 31.3 & 7.03 & 673 & 31.3 & 6.58 & 119 & 31.1 & 7.30 & 363 & 28.1 & 8.14 & 3 & 35.3 & 5.19 & 19 \\
\hline & 関東 & 29.7 & 6.24 & 220 & 30.5 & 6.37 & 55 & 29.6 & 6.36 & 83 & 25.2 & - & 1 & 27.8 & 5.27 & 3 \\
\hline \multirow{2}{*}{ 下 } & 近畿 & 32.7 & 6.86 & 367 & 32.4 & 6.89 & 54 & 32.1 & 6.97 & 205 & 39.3 & - & 1 & 36.7 & 3.80 & 16 \\
\hline & 東海 & 29.7 & 8.23 & 86 & 27.4 & 3.48 & 10 & 30.0 & 8.60 & 75 & 20.0 & - & 1 & - & - & 0 \\
\hline
\end{tabular}

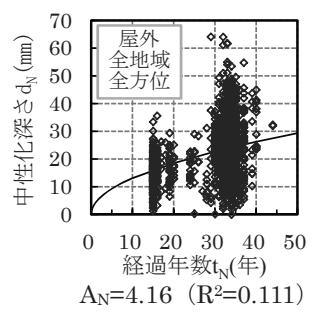

(a)

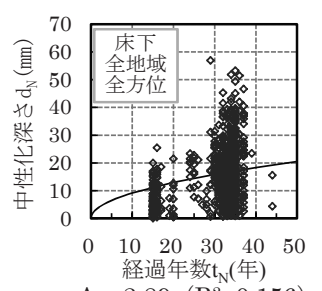

(f)

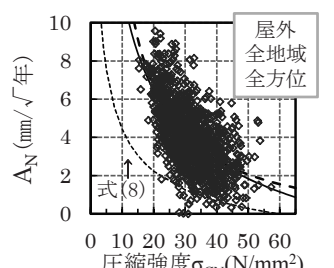

式(3) $\mathrm{a}=152, \mathrm{~b}=0.006\left(\mathrm{R}^{2}=0.423\right)$ 式(4) $\mathrm{a}=56.1, \mathrm{~b}=0.109\left(\mathrm{R}^{2}=0.415\right)$

(a)

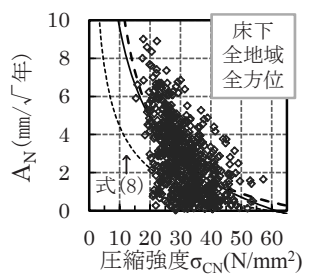

式(3) $\mathrm{a}=138, \mathrm{~b}=0.013\left(\mathrm{R}^{2}=0.335\right)$ 式(4) $\mathrm{a}=50.8, \mathrm{~b}=0.128\left(\mathrm{R}^{2}=0.329\right)$

(f)

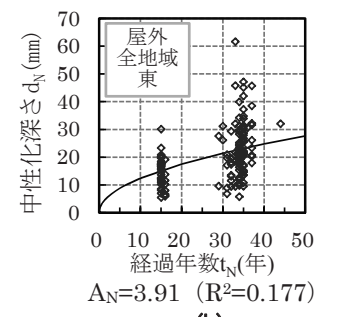

(b)

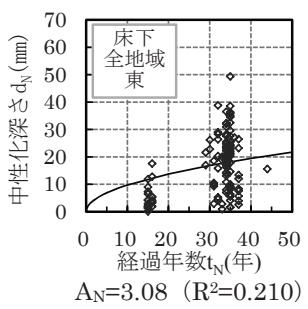

(g)

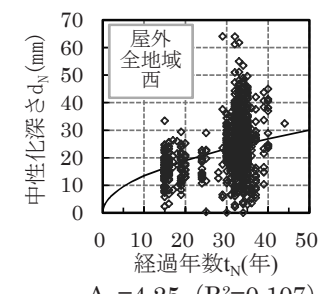

(c)

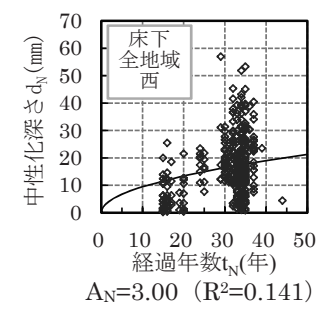

(h)

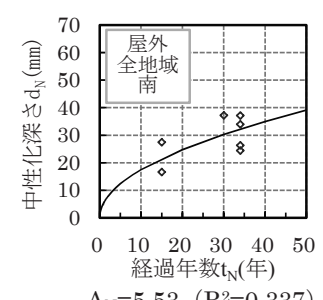

$\mathrm{A}_{\mathrm{N}}=5.53\left(\mathrm{R}^{2}=0.337\right)$

(d)

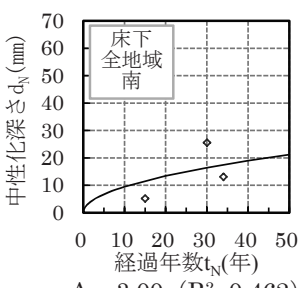

(i)

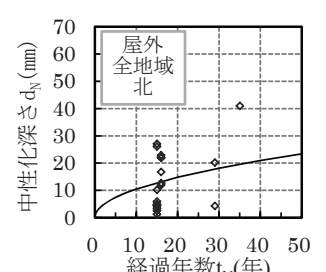

経過年数 $\mathrm{t}$ (年)

$\mathrm{A}_{\mathrm{N}}=3.31 \quad\left(\mathrm{R}^{2}=0.198\right)$

(e)

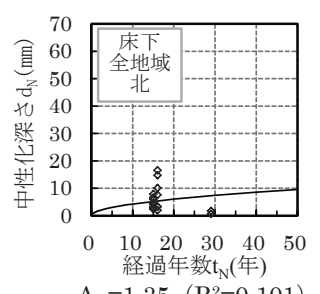

(j)

図 12 経過年数と中性化深さの関係

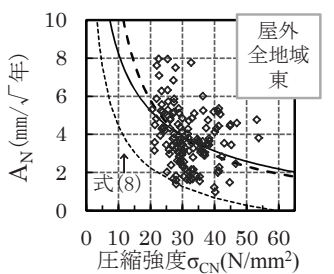

式(3) $\mathrm{a}=116, \mathrm{~b}=0.000\left(\mathrm{R}^{2}=0.173\right)$ 式(4) $\mathrm{a}=32.4, \mathrm{~b}=0.062\left(\mathrm{R}^{2}=0.151\right.$ (b)

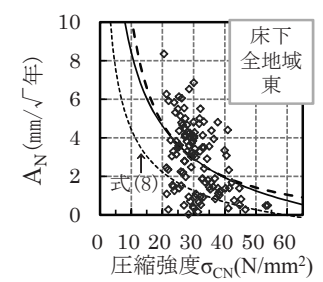

式(3) $\mathrm{a}=111, \mathrm{~b}=0.007\left(\mathrm{R}^{2}=0.164\right)$ 式(4) $\mathrm{a}=41.1, \mathrm{~b}=0.111\left(\mathrm{R}^{2}=0.171\right.$ (g)

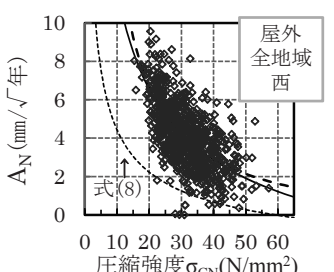

式(3) $\mathrm{a}=153, \mathrm{~b}=0.006\left(\mathrm{R}^{2}=0.464\right)$ 式(4) $\mathrm{a}=56.5, \mathrm{~b}=0.108\left(\mathrm{R}^{2}=0.456\right)$ (c)

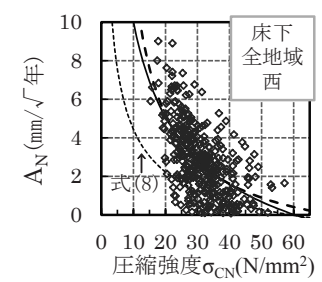

式(3) $\mathrm{a}=144, \mathrm{~b}=0.014\left(\mathrm{R}^{2}=0.395\right)$ 式(4) $\mathrm{a}=53.4, \mathrm{~b}=0.129\left(\mathrm{R}^{2}=0.384\right)$ (h)

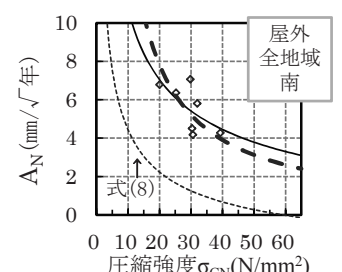

圧縮強度 $\sigma_{\mathrm{CN}}\left(\mathrm{N} / \mathrm{mm}^{2}\right)$

式(3) $\mathrm{a}=156, \mathrm{~b}=0.000\left(\mathrm{R}^{2}=0.405\right)$ 式(4) $\mathrm{a}=39.6, \mathrm{~b}=0.046\left(\mathrm{R}^{2}=0.416\right)$ (d)

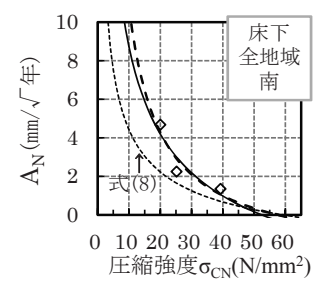

式(3) $\mathrm{a}=131, \mathrm{~b}=0.017\left(\mathrm{R}^{2}=0.882\right)$ 式(4) $\mathrm{a}=49.1, \mathrm{~b}=0.138\left(\mathrm{R}^{2}=0.851\right)$ (i)

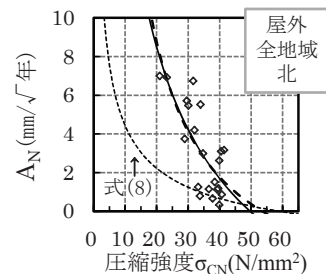

式(3) $\mathrm{a}=280, \mathrm{~b}=0.019\left(\mathrm{R}^{2}=0.571\right)$ 式(4) $\mathrm{a}=104, \mathrm{~b}=0.142\left(\mathrm{R}^{2}=0.582\right)$ (e)

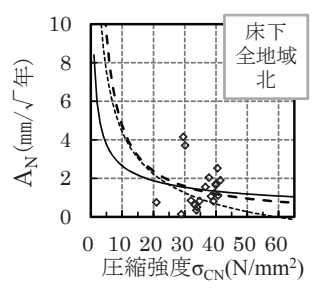

式(3) $\mathrm{a}=47.5, \mathrm{~b}=0.000\left(\mathrm{R}^{2}=0.003\right)$ 式(4) $\mathrm{a}=8.4, \mathrm{~b}=0.000 \quad\left(\mathrm{R}^{2}=0.002\right)$ (j)

図中の回帰曲線の凡例：式(3)破線--- - , 式(4)実線——, 式(8) 点線 --------

図 13 圧縮強度と中性化速度係数 $A_{N}$ の関係 


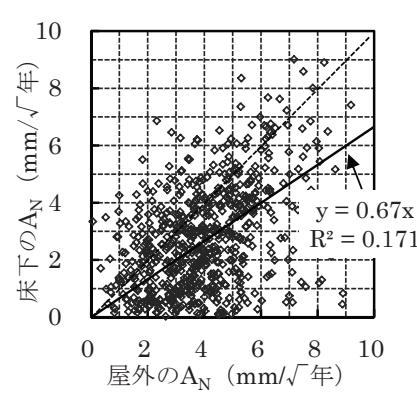

図 14 貫通コアにおける屋外と 床下の中性化速度係数 $A_{N}$ の 関係

$$
\mathrm{A}_{\mathrm{N}}=23.8\left(1 / \sqrt{\sigma_{\mathrm{c} 28}}-0.11\right)
$$

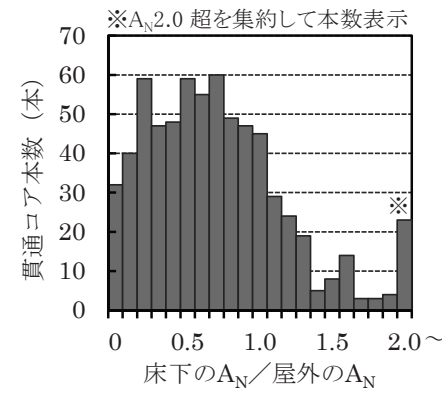

図 15 屋外に対する床下の中性 化速度係数 $A_{N}$ の比率と度 数分布
れ求めた結果を破線および実線であわせて示す。また，図中には， 長谷川らの提案 ${ }^{32}$ ) による $\sigma \mathrm{C} 28$ と屋外暴露試験結果の $\mathrm{A}_{\mathrm{N}}$ に基づいた 関係式である式（8）についても点線で示した。

建設時の設計基準強度は $16.5 \sim 21 \mathrm{~N} / \mathrm{mm}^{2}$ の範囲にあるのに対し て, $\sigma \mathrm{CN}$ は表 7 に示すように全体の平均値で $31.2 \mathrm{~N} / \mathrm{mm}^{2}$ あり, 設 計基準強度を大きく上回っている。 $\mathrm{A}_{\mathrm{N}}$ では方位別の違いが明確に表 れたが， $\sigma \mathrm{CN}$ はデー夕数の多い東面と西面を比べるとほぼ同じであ る。地域間の違いに着目すると, 平均值が最も大きい近畿が $32.1 \mathrm{~N} / \mathrm{mm}^{2}$, 最も小さい東海が $29.3 \mathrm{~N} / \mathrm{mm}^{2}$ とその差は $3 \mathrm{~N} / \mathrm{mm}^{2}$ 未 満である。標準偏差は，東海が一番大きく $7.90 \mathrm{~N} / \mathrm{mm}^{2}$ である。

図 13 に示寸 $\mathrm{A}_{\mathrm{N}}$ と $\sigma \mathrm{CN}$ の関係は図 5 と同様に, ばらつきが見られ るものの全体的には $\sigma \mathrm{CN}$ が大きくなるほど $\mathrm{A}_{\mathrm{N}}$ が小さくなる傾向が 認められる。図 $13(\mathrm{a}) \sim(\mathrm{e})$ の屋外に比べて, 図 $13(\mathrm{f}) \sim(\mathrm{j})$ の床下のデータは全体的に縦軸 $\mathrm{A}_{\mathrm{N}}$ の小さい位置にプロットされ, $30 \mathrm{~N} / \mathrm{mm}^{2}$ 付近から $\mathrm{A}_{\mathrm{N}}$ がほぼ 0 に近いデータもある。自然環境では, $\mathrm{A}_{\mathrm{N}}$ は強度に依存するだけではなく, 湿度などの他の要因が強度との 関係以上に中性化の進行に影響を与えている場合があることがわか る。例えば，図 $13 （ \mathrm{j}$ ）の床下・北面のように, 20〜 $40 \mathrm{~N} / \mathrm{mm}^{2}$ の 範囲において $\mathrm{A}_{\mathrm{N}}$ がほとんど 2 以下となるように中性化の進行が抑 制されている環境では，強度との相関性は表れにくい。

式（3）および式（4）の回帰式の適用について比較すると，図 13 で示す 10 ケースの図のうち, (a) 〜 (c), (f), (h) 〜 (j) の 7 ケースにおいて, 式（3）の方が極めて若干の差であるが高い相関 性を示し，全体的に，実建築物の $\mathrm{A}_{\mathrm{N}}$ は $\sigma \mathrm{CN}$ に反比例するとした考 え方を適用する方が良い結果を示した。データ数が増加すると, 特 に $20 \mathrm{~N} / \mathrm{mm}^{2}$ 付近において $\mathrm{A}_{\mathrm{N}}$ の值が大きい側にばらつくデータが多 くなり，この傾向に対する適合が式（3）の方が相対的に良いこと が関係していると思われる。なお， $50 \mathrm{~N} / \mathrm{mm}^{2}$ 以上については，デー 夕数が少ないため, その範囲における適用の精度には課題が残る。

また, 実建築物における $\sigma \mathrm{CN}$ と $\mathrm{A}_{\mathrm{N}}$ との各関係式と屋外暴露試験 による式 (8) の比較では, 図 13 に示すように, いずれの環境条件・ 方位においても実建築物の $\mathrm{A}_{\mathrm{N}}$ の方が大きい傾向にあり, 同一強度 で見ると $2 \sim 3$ 倍程度大きいことは春畑らの報告 9 ) と同様である。ま た，同一の $\mathrm{A}_{\mathrm{N}}$ で見た場合で比較すると，例えば，図 13 (a) や (f) における $\mathrm{A}_{\mathrm{N}}=4$ において，15〜30 N/mm² 以上の開きがある。この $\mathrm{A}_{\mathrm{N}}$ の違いは, 実建築物の構造体と暴露試験供試体における施工条件 や養生条件の違いに起因するほか, 本分析に用いた $\sigma_{\mathrm{CN}}$ は築 15 年以
上経過した建築物の構造体から採取したコア圧縮強度であるのに対 して, 式 (8) の算出では標準養生供試体による材齢 28 日圧縮強度 $\sigma \mathrm{C} 28$ を用いていることから, 評価するコンクリート強度の材齢に違 いがあることも影響していると思われる。

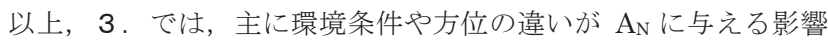
について多くのデータに基づき示した。しかし，採取データの条件 に偏りがあること， $50 \mathrm{~N} / \mathrm{mm}^{2}$ 以上のデータ数が少ないことなどが 課題である。今後, 様々な環境条件において, その条件を客観的に 示す指標をあわせて記録した上で多くの中性化データを収集し, 総 括的に検討する必要があると考えられる。

\section{4. 促進中性化の進行と自然環境における実建築物の中性化の進 行の関係}

\section{1 中性化速度係数比 $\mathrm{R}$ の算出}

2.で分析した促進中性化試験の結果から，3．で分析した自然 環境における実建築物の中性化の進行を予測する手法について検討 する。促進中性化試験に対する自然環境の中性化速度係数比 R は次 式で表される。

$\mathrm{R}=\mathrm{A}_{\mathrm{N}} / \mathrm{A}_{\mathrm{A}}$

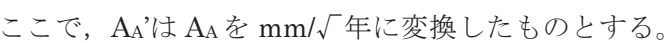

自然環境では $0.03 \sim 0.05 \%$ の低 $\mathrm{CO}_{2}$ 濃度条件であるのに対し, 促 進試験では $5.0 \%$ の高 $\mathrm{CO}_{2}$ 濃度条件である。従来の方法では, 式 (10), 式（11）に示すように両環境における $\mathrm{CO}_{2}$ 濃度と中性化期間の積で ある $\mathrm{CO}_{2}$ 積算量（\%年）が同一になった時，両環境の中性化深さが 同じ $\left(\mathrm{d}_{\mathrm{N}}=\mathrm{d}_{\mathrm{A}}\right)$ になるという考え方に基づいて評価している。

$$
\mathrm{C}_{\mathrm{A}} \mathrm{t}_{\mathrm{A}}{ }^{\prime}=\mathrm{C}_{\mathrm{N}} \mathrm{t}_{\mathrm{N}}
$$

$\mathrm{t}_{\mathrm{A}}{ }^{\prime} / \mathrm{t}_{\mathrm{N}}=\mathrm{C}_{\mathrm{N}} / \mathrm{C}_{\mathrm{A}}$

ここで, $\mathrm{C}_{\mathrm{A}}$ : 促進試験の $\mathrm{CO}_{2}$ 濃度 $(5.0 \%), \mathrm{C}_{\mathrm{N}}$ : 自然環境の $\mathrm{CO}_{2}$ 濃度, $\mathrm{t}_{\mathrm{A}}{ }^{\prime}$ : 促進期間 (年), $\mathrm{t}_{\mathrm{N}}$ : 自然環境の中性化期間（年）とする。 従って，これまで R は式 (12)，式（13）で表されていた例えば,2)。 よって, R は $\mathrm{C}_{\mathrm{N}}$ を屋外 $0.05 \%$ と仮定した場合に 0.1 となる。また, $\mathrm{t}_{\mathrm{N}} / \mathrm{t}_{\mathrm{A}}{ }^{\prime}$ は $\mathrm{CO}_{2}$ 濃度比 5.0/0.05=100になり, 促進中性化試験によって 自然環境の中性化期間を 100 倍短縮していることになる。

$$
\begin{aligned}
& \mathrm{A}_{\mathrm{N}} / \mathrm{A}_{\mathrm{A}}{ }^{\prime}=\sqrt{\mathrm{t}_{\mathrm{A}} / \mathrm{t}_{\mathrm{N}}} \\
& \mathrm{R}=\sqrt{\mathrm{C}_{\mathrm{N}} / \mathrm{C}_{\mathrm{A}}}
\end{aligned}
$$

一方, 本研究で得られた促進中性化試験と自然環境の実建築物の 中性化の関係を図 16 に示す。図中の $\mathrm{AA}_{\mathrm{A}}$ 'は式（5）の単位を「年（1 年 $=52$ 週）に変換した式（14），また， $\mathrm{A}_{\mathrm{N}}$ は自然環境の中性化速度 係数である。ここで $\mathrm{A}_{\mathrm{N}}$ は環境条件別の平均的な傾向を把握するた めに，図 13 の(a)に示寸全地域・全方位の屋外のデータに基づいて 式（3）を適用した式（15）および図 13 の(f)に示す全地域・全方位 の床下のデータに基づいて式（3）を適用した式（16）を一例とし て用いることとし図中にグラフ化した。 R は, 式（14）と式（15） および式（14）と式（16）をそれぞれ式（9）に代入した結果を図 中でグラフ化した。また, 図 17 に, 式（14）と式（15）および式 


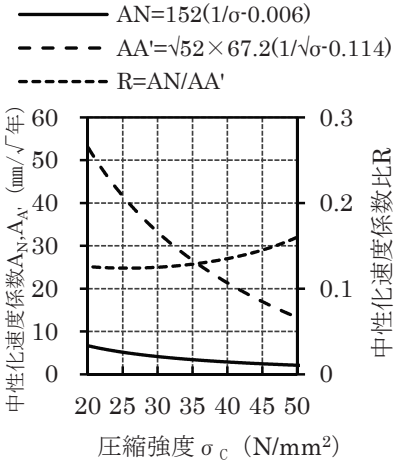

(a) 屋外

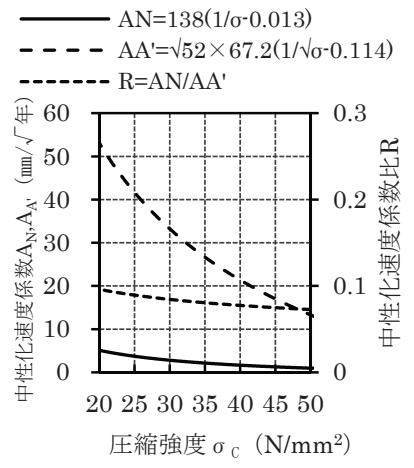

(b) 床下

図 16 中性化速度係数比と圧縮強度の関係

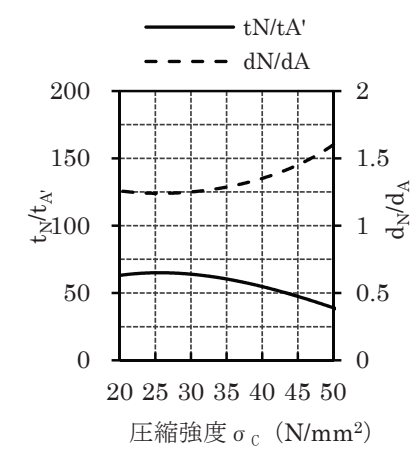

(a) 屋外

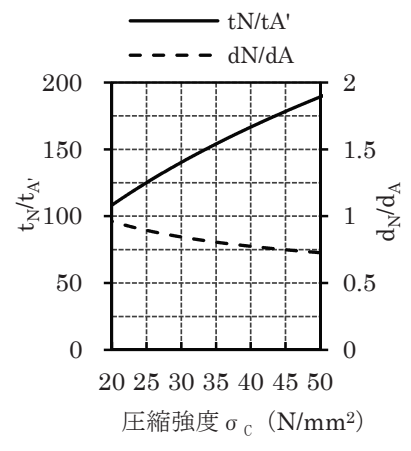

(b) 床下

図 $17 t_{N} / t_{A}^{\prime}$ および $d_{N} / d_{A}$ と圧縮強度の関係

\section{表 8 促進中性化と自然環境の中性化の関係}

(a) 屋外

\begin{tabular}{|c|c|c|c|c|c|c|c|c|c|c|}
\hline $\begin{array}{l}\text { 圧縮强度 } \\
\left(\mathrm{N} / \mathrm{mm}^{2}\right)\end{array}$ & & $\begin{array}{l}A_{N} \\
m / \sqrt{ } \text { 年) }\end{array}$ & & $\begin{array}{l}A_{A}^{\prime} \\
n / V^{\prime} \text { 年) }\end{array}$ & $\left(=A_{N}\right.$ & $\begin{array}{l}R \\
\left.\text { R } / A_{A}^{\prime}\right)\end{array}$ & & ${ }_{N} / t_{A}$ & & $\begin{array}{c}\mathrm{d}_{\mathrm{N}} / \mathrm{d}_{\mathrm{A}} \\
\left(\mathrm{C}_{\mathrm{N}} \mathrm{t}_{\mathrm{N}}=\mathrm{C}_{\mathrm{A}} \mathrm{t}_{\mathrm{A}}{ }^{\prime}\right)\end{array}$ \\
\hline $20 \sim 25$ & 6.7 & $\begin{array}{l}\sim 5.2 \\
\sim\end{array}$ & (53.1 & $\begin{array}{ll}\sim & 41.7\end{array}$ & 0.13 & $\begin{array}{ll}0.12 \\
\sim\end{array}$ & $\begin{array}{l}63.1 \\
\end{array}$ & 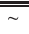 & " 65.0 & $1.26 \sim 1.24$ \\
\hline $25 \sim 30$ & 5.2 & $\sim 4.2$ & 41.7 & $\sim 33.2$ & 0.12 & $\sim 0.13$ & 65.0 & $\sim$ & 64.0 & $1.24 \sim 1.25$ \\
\hline $30 \sim 35$ & 4.2 & $\sim 3.4$ & 33.2 & $\sim \quad 26.7$ & 0.13 & $\sim 0.13$ & 64.0 & $\sim$ & 60.4 & $1.25 \sim 1.29$ \\
\hline $35 \sim 40$ & 3.4 & $\sim 2.9$ & 26.7 & $\begin{array}{l}\sim \\
\sim\end{array}$ & 0.13 & $\sim 0.14$ & 60.4 & $\sim$ & 54.8 & $1.29 \sim 1.35$ \\
\hline $40 \sim 45$ & 2.9 & $\sim 2.5$ & 21.4 & $\sim \quad 17.0$ & 0.14 & $\sim 0.15$ & 54.8 & $\sim$ & 47.5 & $1.35 \sim 1.45$ \\
\hline $45 \sim 50$ & 2.5 & $\sim 2.1$ & 17.0 & $\sim \quad 13.4$ & 0.15 & $\sim 0.16$ & 47.5 & $\sim$ & 39.0 & $1.45 \sim 1.60$ \\
\hline $20 \sim 50$ & 6.7 & $\begin{array}{l}\quad 2.1 \\
\sim\end{array}$ & 53.1 & $\sim \quad 13.4$ & 0.12 & $\sim 0.16$ & 65.0 & $\sim$ & 39.0 & $1.24 \sim 1.60$ \\
\hline
\end{tabular}

(b) 床下

\begin{tabular}{|c|c|c|c|c|c|c|c|c|c|c|c|c|c|}
\hline \multirow{2}{*}{$\begin{array}{c}\begin{array}{r}\text { 圧縮強度 } \\
\left(\mathrm{N} / \mathrm{mm}^{2}\right)\end{array} \\
20 \sim 25\end{array}$} & \multicolumn{2}{|c|}{$\begin{array}{c}\mathrm{A}_{\mathrm{N}} \\
(\mathrm{mm} / \sqrt{ } \text { 年 })\end{array}$} & \multicolumn{3}{|c|}{$\begin{array}{c}\mathrm{A}_{\mathrm{A}}{ }^{\prime} \\
(\mathrm{mm} / \sqrt{ } \text { 年 })\end{array}$} & \multicolumn{3}{|c|}{$\begin{array}{c}\mathrm{R} \\
\left(=\mathrm{A}_{\mathrm{N}} / \mathrm{A}_{\mathrm{A}}{ }^{\prime}\right)\end{array}$} & \multicolumn{3}{|c|}{$\begin{array}{c}\mathrm{t}_{\mathrm{N}} / \mathrm{t}_{\mathrm{A}}{ }^{\prime} \\
\left(\mathrm{d}_{\mathrm{N}}=\mathrm{d}_{\mathrm{A}}\right)\end{array}$} & \multicolumn{2}{|c|}{$\begin{array}{c}\mathrm{d}_{\mathrm{N}} / \mathrm{d}_{\mathrm{A}} \\
\left(\mathrm{C}_{\mathrm{N}} \mathrm{t}_{\mathrm{N}}=\mathrm{C}_{\mathrm{A}} \mathrm{t}_{\mathrm{A}}{ }^{\prime}\right)\end{array}$} \\
\hline & $\begin{array}{ll}5.1 \\
\end{array}$ & $\begin{array}{c}\sim 3.7 \\
\sim\end{array}$ & 53.1 & $\sim$ & 41.7 & 0.10 & $\bar{\sim}$ & 0.09 & 108.2 & $\sim$ & 125.1 & 0.96 & $\sim 0.89$ \\
\hline $25 \sim 30$ & 3.7 & $\sim 2.8$ & 41.7 & $\sim$ & 33.2 & 0.09 & $\sim$ & 0.08 & 125.1 & $\sim$ & 140.2 & 0.89 & $\sim 0.84$ \\
\hline $30 \sim 35$ & 2.8 & $\sim 2.1$ & 33.2 & $\sim$ & 26.7 & 0.08 & $\sim$ & 0.08 & 140.2 & $\sim$ & 154.0 & 0.84 & $\sim 0.81$ \\
\hline $35 \sim 40$ & 2.1 & $\sim 1.7$ & 26.7 & $\sim$ & 21.4 & 0.08 & $\sim$ & 0.08 & 154.0 & $\sim$ & 166.6 & 0.81 & $\sim 0.77$ \\
\hline $40 \sim 45$ & 1.7 & $\sim 1.3$ & 21.4 & $\sim$ & 17.0 & 0.08 & $\sim$ & 0.07 & 166.6 & $\sim$ & 178.3 & 0.77 & $\sim 0.75$ \\
\hline $45 \sim 50$ & 1.3 & $\sim 1.0$ & 17.0 & $\sim$ & 13.4 & 0.07 & $\sim$ & 0.07 & 178.3 & . & 189.0 & 0.75 & $\sim 0.73$ \\
\hline $20 \sim 50$ & 5.1 & $\begin{array}{c}\sim 1.0 \\
\sim\end{array}$ & 53.1 & $\sim$ & 13.4 & 0.10 & $\sim$ & 0.07 & 108.2 & & 189.0 & 0.96 & $\sim 0.73$ \\
\hline
\end{tabular}

（14）と式（16）の各中性化速度係数を用いて，式（1）と式（6） の中性化深さが等しくなるとき $\left(\mathrm{d}_{\mathrm{A}}=\mathrm{d}_{\mathrm{N}}\right)$ の $\mathrm{t}_{\mathrm{N}} / \mathrm{t}_{\mathrm{A}}$ 'および $\mathrm{C}_{\mathrm{N}}$ を屋外 $0.05 \%$ と仮定した場合に式（10）が成立するときの $\mathrm{d}_{\mathrm{N}} / \mathrm{d}_{\mathrm{A}}$ を求めて 圧縮強度との関係をそれぞれグラフ化した。ただし，ここで適用の 対象とする圧縮強度の範囲は, 3. の検討において実建築物でのデ ータが多くあった 20〜 50N $/ \mathrm{mm}^{2}$ とした。表 8 に, 図 16 および図 17 の縦軸の各数值を $5 \mathrm{~N} / \mathrm{mm}^{2}$ ごとに区分して示す。なお, 圧縮強 度について, 促進中性化試験では材齢 28 日圧縮強度を用いている

のに対して, 実建築物では 15 年以上経過してから採取したコア供 試体の圧縮強度を用いている。コア供試体の圧縮強度は, 材齢 28 日圧縮強度と異なるが，ここでは同じと見なして検討を行った。

$$
\begin{aligned}
& \mathrm{A}_{A^{\prime}}=\sqrt{52} \times 67.2\left(1 / \sqrt{\sigma_{C}}-0.114\right) \\
& \mathrm{A}_{N}=152\left(1 / \sigma_{C}-0.006\right) \\
& \mathrm{A}_{N}=138\left(1 / \sigma_{C}-0.013\right)
\end{aligned}
$$

\section{2 中性化速度係数比 R の比較および考察}

屋外と床下では, $\mathrm{A}_{\mathrm{N}}$ と圧縮強度の関係に違いがあるため, 中性化 速度係数比 $\mathrm{R}$ の傾向についても違いが見られた。促進中性化試験に

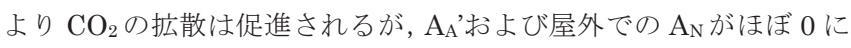
なる圧縮強度の值に大きな差はないため, $\mathrm{R}$ は圧縮強度が大きくな るに伴い 0.12 から 0.16 程度に漸増していく傾向にある。一方, 湿 潤環境である床下では, 屋外と比較して中性化の進行が抑制され, $\mathrm{A}_{\mathrm{N}}$ がほぼ 0 になる圧縮強度の值が $\mathrm{A}_{\mathrm{A}}{ }^{\prime}$ の場合に比べて小さくなるこ とによる影響を受けて, 圧縮強度が大きくなるに伴い逆に $\mathrm{R}$ は 0.10 から 0.07 程度に漸減していく傾向にある。これは従来の計算で用い られている $\mathrm{R}=0.1$ に対し, 自然環境における実建築物の $\mathrm{R}$ は一律で はなく強度や環境条件によって違いが表れることにおいて, 一致し ない結果となった。

なお， 7 年間の屋外暴露試験を行った押田らの研究 33)では, 普通 ポルトランドセメントを使用したコンクリートにおける Rの関係式

$(\mathrm{R}=0.227 /(\mathrm{W} / \mathrm{B})-0.342, \mathrm{~W} / \mathrm{B}:$ 水結合材比）が示されており, W/B 0.4 0.6（材齢 28 日圧縮強度で約 $31 \sim 54 \mathrm{~N} / \mathrm{mm}^{2}$ ) の範囲での $\mathrm{R}$ は 0.04 0.23 であった。本研究では, $20 \sim 50 \mathrm{~N} / \mathrm{mm}^{2}$ の範囲にお ける $\mathrm{R}$ は屋外では $0.12 \sim 0.16$, 床下では $0.10 \sim 0.07$ あ゙あので, 押 田らの研究と比較すると, $30 \mathrm{~N} / \mathrm{mm}^{2}$ 付近では $2 \sim 3$ 倍程度大きい結 果であったが, 圧縮強度が大きい範囲では逆に小さくなっている。

また，本検討における $\mathrm{t}_{\mathrm{N}} / \mathrm{t}_{\mathrm{A}}{ }^{\prime}$ は，屋外では 39〜 65, 床下では 108 〜 189 で, 従来の計算による 100 と一致しないため, $\mathrm{t}_{\mathrm{N}} / \mathrm{t}_{\mathrm{A}}{ }^{\prime}$ は $\mathrm{CO}_{2}$ 濃度に単純に比例すると言えない結果である。さらに, 両環境が同 じ $\mathrm{CO}_{2}$ 積算量になった時, 本検討における $\mathrm{d}_{\mathrm{N}} / \mathrm{d}_{\mathrm{A}}$ は屋外では 1.2 以 上，床下では 1 未満であり， $\mathrm{d}_{\mathrm{N}}=\mathrm{d}_{\mathrm{A}}$ とはならなかった。

本研究において, $\mathrm{CO}_{2}$ 濃度 $5.0 \%$ で $\mathrm{t}_{\mathrm{A}}$ '年の促進試験を行った時の 中性化深さが $\mathrm{d}_{\mathrm{A}}$ のコンクリートについて, 自然環境（屋外 $\mathrm{CO}_{2}$ 濃 度 $0.05 \%)$ における実建築物として $\mathrm{t}_{\mathrm{N}}$ 年経過した屋外側での平均的 な中性化深さ $\mathrm{d}_{\mathrm{N}}$ を予測すると次式で計算できる。

$$
\mathrm{d}_{\mathrm{N}}=\mathrm{RA}_{\mathrm{A}}{ }^{\prime} \sqrt{\mathrm{t}_{\mathrm{N}}}
$$

$$
\mathrm{d}_{\mathrm{N}}=\mathrm{Rd}_{\mathrm{A}} \sqrt{\mathrm{t}_{\mathrm{N}} / \mathrm{t}_{\mathrm{A}}}
$$

ただし， Rの值は表 8 による。

なお, 実建築物の中性化の進行は, 図 13 に示すように湿度や日 射などの環境条件や施工条件・養生条件の違いによる影響を受ける ことから,ここで示す $\mathrm{R}$ は促進中性化試験と自然環境との $\mathrm{CO}_{2}$ 濃度 以外の要因が包含された係数になっている。表 8 の数值は屋外と床 下環境における本研究データに基づいた平均的な数值としての提示 
であり, 今後, 様々な環境条件における中性化データを収集・整理 し，条件に応じた $\mathrm{R}$ を提示する必要があると考える。

\section{5. まとめ}

本研究で得られた成果および知見を以下にまとめる。

（1）文献調査を行い，普通ポルトランドセメントを使用したコンク リートの促進中性化試験 68 データによる促進中性化の総括的 傾向を検討し, 促進中性化速度係数と水セメント比および促進 中性化速度係数と圧縮強度の関係式を示した。

（2）自然環境における䇋工後 15 年以上経過した実建築物の打放し コンクリートの部位から採取したコア 1210 本について, 環境 条件, 方位および地域別に分類して中性化速度係数を算出し, その違いが及ぼす影響の度合いについて定量的に把握した。湿 度が高い床下環境では, 屋外に比べて中性化速度係数は 0.7 倍 程度に抑制されている。屋外の方位別では, 南面>西面>東面 $>$ 北面の順に中性化速度係数が大きく, その幅は 1.67 倍程度 である。屋外の地域別では, 近畿と東海に比べると関東の中性 化速度係数が比較的大きい。また, 中性化速度係数と圧縮強度 の関係式を示した。

（3）（1)拉よび(2)の結果を用いて, 圧縮強度 $20 \sim 50 \mathrm{~N} / \mathrm{mm}^{2}$ の範囲で 促進中性化試験に対する自然環境の中性化速度係数比 $\mathrm{R}$ の算 出事例を示した。自然環境における実建築物の屋外側の平均的 な中性化に関して, $\mathrm{R}$ は $0.12 \sim 0.16$ を示し, 圧縮強度が大き くなるほど R は大きくなる傾向にあった。一方, 湿潤環境であ る床下側では, $\mathrm{R}$ は 0.10〜0.07 を示し，圧縮強度が大きくな るほど R は逆に小さくなる傾向にあった。

\section{謝辞}

本研究を実施するにあたり, 既往の促進中性化試験データの収集 および整理には，宇都宮大学大学院（当時）の SUSAN 氏の協力を 得た。また, 実建築物のコンクリートコアデータについては, 建築 物所有者の承諾のもと（一社）建築研究振興協会八王子試験所から 提供していただいた。ここに記して感謝の意を表します。

\section{参考文献}

1）建設大臣官房技術調查室 : 鉄筋コンクリート造建築物の而久性向上技術, p. 196, 技報堂出版, 1986

2）日本建築学会 : 鉄筋コンクリート造建築物の耐久設計施工指針（案）・ 同解説，pp. 92-108, 2004

3）阿部道彦ほか 5 名: コンクリートの促進中性化試験法の評価に関する研 究，日本建築学会構造系論文報告集，第 409 号，pp. 1-10，1990.3

4) 日本建築学会 : 高耐久性鉄筋コンクリート造設計施工指針（案）・同解 説, 1991.7

5）依田彰彦：40 年間自然暴露した高炉セメントコンクリートの中性化と 仕上材の効果, セメント・コンクリート論文集, No. 56, pp. 449-454, 2002. 12

6）和泉意登志ほか 1 名: 経年建築物におけるコンクリートの中性化と鉄筋 の腐食，日本建築学会構造系論文報告集，第 406 号，pp. 1-12，1989. 12

7）川西泰一郎ほか 2 名: 実建物調査に基づくコンクリートの中性化進行に 関する分析, 日本建築学会構造系論文集, 第 608 号, pp. 9-14, 2006. 10

8）玉井孝幸ほか 4 名：1953 年から 1985 に建設された建物の構造体コンク リートの中性化の実態, 日本建築学会技術報告集, vol. 13, No. 25, pp. 1-6, 2007.6

9）春畑仁一ほか 2 名: 既存鉄筋コンクリート造建築物のコンクリート材料 調査における圧縮強度と中性化深さの統計，その 1 ，その 2 , 日本建築
学会大会学術講演梗概集 A-1，pp. 549-552，2011.8

10）黒島毅ほか 1 名: 砕石粉を用いた高流動コンクリートに関する研究，そ の 5, 日本建築学会大会学術講演梗概集 A-1, pp. 239-240, 1995.8

11）中村則清ほか 3 名: コンクリートの促進中性化試験結果のばらつきに関 する実験的検討, 2008 年度日本建築学会関東支部研究報告集, pp. 109-112, 2009. 3

12）中村則清ほか 4 名: コンクリートの促進中性化に及ぼす試験方法上の要 因の影響, その 4, 日本建築学会大会学術講演梗概集 A-1, pp. 1149-1150, 2005. 9

13）中村則清ほか 3 名: コンクリートの促進中性化に及ぼす試験方法上の要 因の影響，コンクリート工学年次論文集，vol. 25, No. 1，pp. 761-766, 2003

14）大和功一郎ほか 3 名：PCa コンクリートの促進中性化に関する研究，コ ンクリート工学年次論文集, vol. 31, No. 1, pp. 943-948, 2009

15）和田利之ほか 2 名: 低発熱型セメントを用いたコンクリートの中性化特 性，コンクリート工学年次論文集，vol.23，No. 2，pp. 451-456，2001

16）大和功一郎ほか 3 名:各種 $\mathrm{PCa}$ コンクリートの促進中性化に関する研究, コンクリート工学年次論文集，vol. 32，No. 1，pp.647-652，2010

17）黒岩秀介ほか 5 名: 保水性を有する新収縮低減剤を混和したコンクリー 卜の実用化, その 2, 日本建築学会大会学術講演梗概集 A-1, pp. 455-456, 2011.8

18）山下修平ほか 3 名:各種セメントを用いたコンクリートの促進中性化試 験方法の検討, 2010 年度日本建築学会関東支部研究報告集, pp. 45-48, 2011.3

19）久保田浩ほか 3 名: 中性化抑制効果に優孔た水系ふつ素樹脂クリヤ塗装 仕様の開発，促進中性化試験結果，日本建築学会大会学術講演梗概集 A-1, pp. 463-464, 2008. 9

20）守屋健一ほか 5 名: フライアッシュコンクリートの中性化に関する研究, その 1, 日本建築学会大会学術講演梗概集 A-1, pp. 389-390, 2007.8

21）松本幸太郎ほか 5 名: 降雨の影響を受ける構造体コンクリートの中性化 速度に関する研究, 日本建築学会中国支部研究報告集, 第 36 巻, pp. 33-36, 2013. 3

22）松浦誠司ほか 3 名:使用材料が吹付けコンクリートの耐久性に及ぼす影 響，コンクリート工学年次論文集，vol. 22，No. 2，pp. 1375-1380，2000

23）石川嘉崇ほか 2 名：各種スラグ細骨材との性状比較による IGCC 石炭溶 融スラグのコンクリート用細骨材としての有用性の検討, 日本建築学会 構造系論文集，第 676 号, pp. 799-805, 2012.6

24）全洪珠ほか 1 名: コンクリートの強度および而久性に及ぼすフライアッ シュの種類・置換率の影響に関する実験的研究, 日本建築学会構造系論 文集，第 602 号，pp. 1-7，2006.4

25）日本建築学会：コンクリートの調合設計・調合管理・品質検査指針案・ 同解説, p. 84, 1976

26）和泉意登志：コンクリートの中性化速度に関する研究，日本建築学会構 造系論文集，第 394 号，pp. 17-26，1988.12

27）和泉意登志 : コンクリートの中性化に及ぼすセメントの種類, 調合およ び養生条件の影響について, 第 7 回コンクリート工学年次講演会論文集, pp. 117-120, 1985

28) H. G. Smolczyk : Written discussion on Carbonation of Concrete by M. Hamada, Proc. of 5 th International Symposium on the Chemistry of Cement, Vol. 3 Tokyo, pp. 369-384, 1968

29）橋本佳大ほか 1 名: 地表面の跳衩返り雨水による外壁面足下部の濡孔に 関する実験的研究, 日本建築学会大会学術講演梗概集 A-1, pp. 279-280, 2002.8

30）畑中稔臣ほか 4 名：戸建住宅の床下温湿度性状に関寸る研究，平成 10 年度日本建築学会近畿支部研究報告集, pp. 237-240, 1998.5

31）岩前篤ほか 3 名: 戸建て住宅の床下温湿度性状に関寸る研究 (その 2), 平成 11 年度日本建築学会近畿支部研究報告集, pp. 93-96, 1999.5

32）長谷川拓哉ほか 1 名 : 文献調査に基づく屋外の中性化進行予測，コンク リート工学年次論文集, vol. 28, No. 1, pp. 665-670, 2006

33）押田文雄ほか 5 名: 中庸熱フライアッシュセメントを使用したコンクリ 一トの中性化速度係数, 日本建築学会技術報告集, Vol. 20, No. 45, pp. 451-456, 2014. 6 


\title{
ANALYSIS ON NATURAL CONCRETE CARBONATION OF ACTUAL BUILDINGS AND SUGGESTION FOR ITS PREDICTION METHOD
}

\author{
Takehiko TANUMA* and Hisashi SUGIYAMA** \\ * Grad. Stud., Dept. of Architecture, Utsunomiya Univ., M.Eng. \\ Senior Research Engineer, Building Research Institute \\ ** Prof., Dept. of Architecture, Utsunomiya Univ., Dr.Eng.
}

Before using newly developed concrete in actual buildings, it is a common practice to confirm the carbonation rate and durability of the new concrete using an accelerated carbonation test.

However, an accelerated carbonation test can only provide a relative indication of the concrete carbonation rate and cannot clearly indicate how fast the test accelerates the carbonation rate of concrete in natural environments. Furthermore, no study exists in which the results of an accelerated carbonation test have been compared with results of a carbonation test on concrete used in existing buildings subjected to natural environments.

In this study, we propose a method for estimating the carbonation rate of concrete that will be used in actual buildings and subjected to natural environments. This method is established on the basis of results of an accelerated carbonation test and by taking the following three steps:

(1) Collection and analysis of past accelerated carbonation test data.

(2) Understanding of the actual progress of concrete carbonation in existing buildings subjected to natural environments.

(3) Proposal of a carbonation rate coefficient ratio (R) that correlates results of an accelerated carbonation test to results of a carbonation test in existing buildings.

The results for each step are:

(1) Data of 68 accelerated carbonation tests were collected. From these data, an equation relating the accelerated carbonation rate coefficient and water-cement ratio as well as an equation relating the accelerated carbonation rate coefficient and concrete compressive strength was derived.

(2) A total of 1210 core samples were taken from the structural concrete of existing buildings and they were sorted into groups according to the environmental conditions, orientations, and regions in which the concrete had been used. The carbonation rate coefficient for each group was calculated, and an equation relating the carbonation rate coefficient and concrete compressive strength was derived.

(3) The ratio (R), which is a ratio of the carbonation rate coefficient obtained in an accelerated carbonation test to that obtained from carbonation testing of the existing buildings, was approximately calculated to be in the range of 0.07-0.16. 